\title{
Removal of Cationic Organic Dye from Aqueous Solution by Chemical and Pyrolysis Activated Ulva lactuca
}

\author{
Nour Houda M'sakni ${ }^{1,2,+}$ and Taghreed Alsufyani ${ }^{1, *,+}$ \\ 1 Department of Chemistry, College of Science, Taif University, P.O. Box 11099, Taif 21944, Saudi Arabia; \\ Nour.h@tu.edu.sa \\ 2 Laboratory of the Interfaces and Advanced Materials (LIMA), Science Faculty, Monastir University, \\ Monastir 5019, Tunisia \\ * Correspondence: Taghreed.alsufyani@tu.edu.sa; Tel.: +966-536324255 \\ + These authors contributed equally to this work.
}

check for updates

Citation: M'sakni, N.H.; Alsufyani, T. Removal of Cationic Organic Dye from Aqueous Solution by Chemical and Pyrolysis Activated Ulva lactuca. Water 2021, 13, 1154. https:// doi.org/10.3390/w13091154

Academic Editor: Alicia Ronda Gálvez

Received: 16 March 2021

Accepted: 19 April 2021

Published: 22 April 2021

Publisher's Note: MDPI stays neutral with regard to jurisdictional claims in published maps and institutional affiliations.

Copyright: (C) 2021 by the authors. Licensee MDPI, Basel, Switzerland. This article is an open access article distributed under the terms and conditions of the Creative Commons Attribution (CC BY) license (https:/ / creativecommons.org/licenses/by/ $4.0 /)$.
Abstract: Ulva lactuca has been used to remove many toxic substances from industrial wastewater. In the present study we tried to optimize the efficiency of $U$. lactuca as an adsorbent of methylene blue (MB) in aqueous solution. U. lactuca was chemically treated with sulfuric acid (UL-H) and sodium hydroxide (UL-OH) and by a slow pyrolysis process (carbonization process) at high temperature $\mathrm{T}=600{ }^{\circ} \mathrm{C}$ (UL-T) and compared to the nonactive Ulva (UL-NA) and the water insoluble substance (UL-WIS). Several spectroscopic analyses were carried out to detect the biosorption mechanisms of Ulva to remove $\mathrm{MB}$ in solution. The effects of different parameters on the adsorption process were studied, i.e., $\mathrm{pH}(2-10)$, mass concentration (1-10 $\left.\mathrm{g} \mathrm{L}^{-1}\right)$, and contact time (0-120 min). The results showed that the best adsorption of $\mathrm{MB}$ by Ulva was at $\mathrm{pH}=8$, with $5 \mathrm{~g} \mathrm{~L}^{-1}$ of biomass at $75 \mathrm{~min}$; the best adsorption capacity was $625.0 \mathrm{mg} \mathrm{g}^{-1}$ for $\mathrm{UL}-\mathrm{OH}$, which was able to remove more than $89 \%$ of MB compared to UL-T, whose removal rate did not exceed $5 \%$. Fourier-transform infrared spectroscopy (FTIR), energy-dispersive X-ray spectroscopy (EDX), and scanning electron microscopy (SEM) indicated the presence of oxygenated functional groups with a highly porous surface. The kinetic studies confirmed that the majority of treatments follow the pseudo-second-order type. The mathematical models showed that Langmuir model is favorable to UL-OH, UL-WIS, and UL-NA. According to the experimental results, the primary treatment for U. lactuca is a promising environmentally friendly method and an economical strategy for removing $\mathrm{MB}$ from aqueous solution. This method can help address the growing demand for adsorbents used in environmental protection processes and the resultant increase in their price.

Keywords: Ulva lactuca; activated biomass; water pollution; cationic dye; adsorption kinetic

\section{Introduction}

The daily use of dyes has caused both environmental and nutritional complications. Environmental pollution is caused by the discharge of industrial wastewater due to the manufacture of plastic, paper, textiles, rubber, cosmetics, leather, food, pharmaceuticals, etc., which creates a large amount of toxic dyes, mutagens, and carcinogens. Biosorption is the most practical technique for recycling industrial wastewater rich in dyes due to its simplicity and economy [1,2]. Consequently, attention has turned to low-cost biomass, which may consist of residues that can be disposed of by other industries, e.g., peanut shells [3], rice husks [4], water hyacinth roots [5], spent bleaching earth extracted with hexane [6], nonactivated and activated date pits [7], guava seeds [8], the macroalga Sargassum muticum [9], Parthenium plants [10], bacteria and fungi [11], etc. In recent years, algae have become one of the most used sources as a disinfectant for wastewater rich in dyes and heavy metals $[12,13]$.

In the current study, Red sea Ulva lactuca was selected to be an adsorbent of methylene blue (MB) dye due to its low-cost availability over the season and its fast blooming, which 
causes green tide worldwide and is hard to control [14]. Thus, it is a good idea to exploit such massive biomass to remove toxic substances from the environment. $U$. lactuca is well known for its efficiency in the defense process through its release of an efficient amount of polyunsaturated aldehyde [15] as well as its ability as an adsorbent of heavy metals [16-18] and toxic substances like dyes [19] and phenols [14]. As a cationic and thiazine dye, $\mathrm{MB}$ is widely applied in several fields, e.g., industry, biology, chemistry, and medicine, which is the reason behind its existence in large amounts in water bodies, contributing to the depletion of the photosynthesis rate and having a direct effect on aquatic organisms, resulting in damage to the water environment $[20,21]$. In this study, MB and U. lactuca were selected for the first time as an adsorbent-adsorbate model with a chemical activation process in the Kingdom of Saudi Arabia (KSA). The key objective of this study was to determine the best MB-U. Lactuca biomass ratio for recycling industrial wastewater in the future. The most essential substances adopted as chemical activating agents of biomass involve compounds of alkali or alkaline earth metals, such as $\mathrm{KOH}, \mathrm{K}_{2} \mathrm{CO}_{3}, \mathrm{Na}_{2} \mathrm{CO}_{3}$, $\mathrm{MgCl}_{2}$, and certain acids and salts, such as $\mathrm{H}_{3} \mathrm{PO}_{4}, \mathrm{H}_{2} \mathrm{SO}_{4}, \mathrm{AlCl}_{3}$, and $\mathrm{ZnCl}_{2}$. The role of these activating agents is to remove water from the structure of the primary material and lower the temperature necessary for carbonization, which contributes to the creation of a porous structure in the biomass [22]. However, the process of physical activation of biomass, namely conventional (or slow) pyrolysis at $550-950{ }^{\circ} \mathrm{C}$, produces charcoal. This residue undergoes a second activation with the aid of water vapor, carbon dioxide $\left(\mathrm{CO}_{2}\right)$, or nitrogen $\left(\mathrm{N}_{2}\right)$ [23]. Previous studies showed that the physical activation method often creates cone-shaped cavities, while the chemical activation method leads to the development of cavities in the form of bottles [24,25]. However, the pores of the biomass must be opened in order to use it as an effective adsorbent. A comparative study analyzed two activation processes: chemical by multiple media $\left(\mathrm{H}_{2} \mathrm{SO}_{4}, \mathrm{NaOH}\right)$; and physical by carbonization (slow pyrolysis) of the biomass at $600{ }^{\circ} \mathrm{C}$ in a graphite furnace for $4 \mathrm{~h}$ under an inert atmosphere, using nitrogen gas before and during heating. Thus, in this work, we sought to improve the feasibility of $U$. lactuca as an adsorbent in KSA to remove MB. For this reason, we studied the effect of several physicochemical quantities and factors influencing the adsorption performance, namely the initial $\mathrm{pH}$, the contact time of the adsorbent-MB, and the dose of adsorbent-adsorbate. These factors can be deduced by validating the kinetic models, including the pseudo-first- and pseudo-second-order kinetics, the Elovich model, and the intraparticle diffusion model as well by the applicability of the Langmuir and Freundlich model for the MB system. We also adopted different spectroscopy analyses, namely FTIR and SEM-EDX, in order to better understand the morphology and the nature of binding that is established in the MB-algae biomass system during the biosorption of basic dyes.

The novelty of this study was the activation of dried $U$. lactuca collected from Red Sea by different chemical and pyrolysis treatments. Most of previous studies utilized $U$. lactuca without activation [26-29]. The obtained results will be significant in addressing the growing demand for adsorbents used in environmental protection processes and the resultant increase in their price.

\section{Materials and Methods}

\subsection{Adsorbate}

The adsorbate used in this study was methylene blue, with the molecular formula $\mathrm{C}_{16} \mathrm{H}_{18} \mathrm{ClN}_{3} \mathrm{~S}$ (319.85 $\mathrm{g} \cdot \mathrm{mol}^{-1}$ ). $\mathrm{MB}$ is an organic dye and was obtained from (MERCK, Darmstadt, Germany) and used without purification. A stock solution of $1600 \mathrm{mg} \cdot \mathrm{L}^{-1}$ $\left(5 \times 10^{-3} \mathrm{~mol} \cdot \mathrm{L}^{-1}\right)$ was prepared using double distilled water. From this solution, a dilution to a concentration of $16 \mathrm{mg} \mathrm{L}^{-1}\left(5 \times 10^{-5} \mathrm{~mol} \cdot \mathrm{L}^{-1}\right)$ was prepared. This concentration was adopted on the basis of the results from [30] (2016), which showed that the biosorption percentage of dyes decreases as the initial dye concentration increases. The calibration curve was plotted at a maximum wavelength of $664 \mathrm{~nm}$ using a UV spectrophotometer (Shimadzu model: UV 1601, Germany). Then, $0.1 \mathrm{M} \mathrm{HCl}$ (Merck) or $0.1 \mathrm{M} \mathrm{NaOH}$ 
(Merck) solutions were used to adjust the $\mathrm{pH}$. The experiments were carried out at room temperature $\left(25 \pm 2{ }^{\circ} \mathrm{C}\right)$. All chemicals were of analytical grade.

\subsection{Adsorbents}

The adsorbents used in this study were green macroalgae thalli ( $U$. lactuca). These green algae were collected from a local coast of the Red Sea in Jeddah $\left(21^{\circ} 38^{\prime} 50^{\prime \prime} \mathrm{N}\right.$, $39^{\circ} 6^{\prime} 5^{\prime \prime}$ E). The thalli were first washed with tap water and then twice washed with distilled water to remove the dirt. They were then dried at room temperature and finally dried at $60{ }^{\circ} \mathrm{C}$ for $24 \mathrm{~h}$ until the mass stabilized. The dried thalli were ground to a fine powder, sieved to obtain particle sizes below $125 \mu \mathrm{m}$, and stored in glass containers.

\subsection{Surface Modification of Algal Biomass}

In order to improve the biosorption surface of $U$. lactuca biomass (UL-NA: non activated $U$. lactuca) and confirm its potential as a natural adsorbent for the treatment of water containing dye, several operating conditions affecting the biosorption of the organic dye were studied. Thus, pretreatment with deionized water for $24 \mathrm{~h}$ and at room temperature was carried out in order to extract the water-soluble fraction from the biomass of dry Ulva with the aim of isolating the water-soluble polysaccharides, proteins, dyes, and mineral salts that may interfere with the measurements; the water-insoluble substance was named UL-WIS.

Activation generates a very porous microstructure, thereby increasing accessibility to the internal structure of Ulva's biomass. It also makes it possible to create surface functions (generally oxidized), which are the origin of the interactions between the solid and the adsorbed species. However, two conventional activation routes were used (Figure 1): physical activation by pyrolysis (SM. 2.3.1) with carbonization at $600^{\circ} \mathrm{C}$ for $4 \mathrm{~h}$ in a graphite furnace and for $4 \mathrm{~h}$ in an inert atmosphere using nitrogen gas before and during heating; chemical activation methods (SM. 2.3.2), which were adapted with some modifications from [31-34], and started by impregnation of the biomass in the form of a small particle size in an aqueous solution containing an activating agent $\left(\mathrm{H}_{2} \mathrm{SO}_{4}\right.$ or $\left.\mathrm{NaOH}\right)$. The latter can cause hydrolysis reactions within the macromolecules, which constitute the lignocellulosic biomass and lead to the solubilization of certain amorphous macromolecules and a destructuring of the lignocellulosic matrix. The adsorption capacities of the different active and nonactive biomasses were tested on the organic pollutant $\mathrm{MB}$ with different $\mathrm{pH}$, algal biomass, and contact time.

\subsection{Characterization of the Modified and Nonmodified Algae}

In general, the properties and pore structure of biomass can be characterized by nitrogen adsorption, X-ray powder diffractometry (XRD), infrared spectroscopy (FTIR) and scanning electron microscopy (SEM). The specific surface area of activated carbon was determined by the Horvath-Kawazoe BET method, the DFT method, and the methylene blue adsorption method (MBAM). In this study, the following procedures were conducted. 


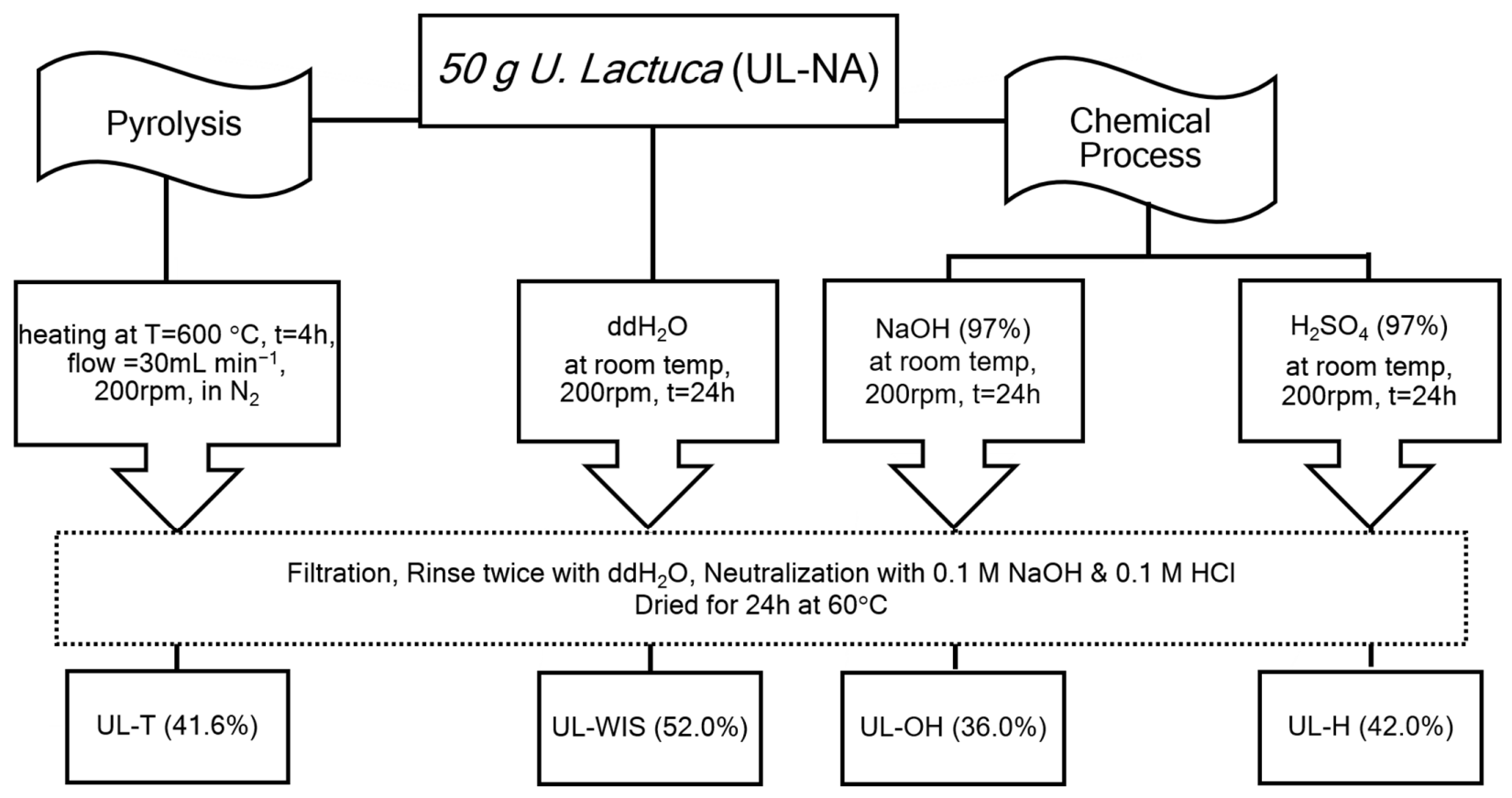

Figure 1. Methods used for activation of $U$. lactuca biomass chemically and using pyrolysis.

\subsubsection{Determination of the Specific Surface Area}

The specific surface area was determined by the methylene blue adsorption method (MBAM). For this purpose, $50 \mathrm{~mL}$ of methylene blue solution (MB) $\left(\mathrm{C}_{0}=5 \times 10^{-5} \mathrm{~mol} \mathrm{~L}^{-1}\right)$ was brought into contact with $1 \mathrm{mg}$ of activated and nonactivated carbon $\left(\mathrm{m}_{\mathrm{C}}\right)$. The suspension is stirred until equilibrium. Samples were taken every ten minutes to make it possible to determine the equilibrium time, and therefore the equilibrium concentration (Ce), of the residual MB solution obtained after centrifugation, by measuring the optical density at $\lambda \max$. We then calculated $\mathrm{Qm}$, the maximum adsorption capacity of activated carbon for $\mathrm{MB}$, using Equation (1).

$$
\mathbf{Q m}=\frac{\left(\mathbf{C}_{0}-\mathbf{C}_{\mathbf{e}}\right) * \mathbf{V}}{m_{\mathbf{C}}} \quad \text { Maximum adsorption capacity }
$$

$$
\mathrm{S}_{\mathrm{MB}}=\mathrm{Qm} . \mathrm{N}_{\mathrm{A}}{ }^{*} \mathrm{~s} \text { specific surface area determined by (MBAM) }
$$

where $\mathrm{Qm}$ is the maximum carbon adsorption capacity for $\mathrm{MB}\left(\mathrm{mol} \cdot \mathrm{g}^{-1}\right)$; Co is the initial concentration of the $\mathrm{MB}$ solution $\left(\mathrm{mol} \mathrm{L}^{-1}\right)$; $\mathrm{Ce}$ is the equilibrium concentration of the MB solution $\left(\mathrm{mol} \mathrm{L}^{-1}\right) ; \mathrm{m}_{\mathrm{C}}$ is the mass of the activated carbon $(\mathrm{g}) ; \mathrm{V}$ is the volume of the solution $(\mathrm{mL})$. The $\mathrm{S}_{\mathrm{MB}}$ specific surface area (determined using MB) [35] is calculated using Equation (2), where $S_{M B}$ is the specific surface area determined using $M B$ as adsorbate $\left(\mathrm{m}^{2} \mathrm{~g}^{-1}\right) ; \mathrm{Qm}$ is the maximum adsorption capacity $\left(\mathrm{mol} \mathrm{g}^{-1}\right) ; \mathrm{N}_{\mathrm{A}}$ is Avogadro's constant; $\mathrm{s}$ is the area occupied by a molecule of $\mathrm{MB}\left(175 \mathrm{~A}^{2}\right)$ [36]. The characteristics of the different dry adsorbents determined are presented in Table 1.

Table 1. Characteristics of the adsorbents: untreated, water insoluble substance, and treated dry U. actuca.

\begin{tabular}{cccccc}
\hline UL-T & UL-OH & UL-WIS & UL-H & UL-NA & \\
\hline 249 & 545 & 437 & 290 & 235 & ${\text { Qm }\left(\mathrm{mol} \mathrm{g}^{-1}\right)}^{-1}$ \\
263 & 575 & 460 & 305 & 247 & S $_{\text {MB }}\left(\mathrm{m}^{2} \mathrm{~g}^{-1}\right)$ \\
\hline
\end{tabular}




\subsubsection{FTIR Analysis}

The raw (UL-NA), water insoluble substance (UL-WIS), and activated (UL-OH, UL-H, UL-T) algae were analyzed by FTIR (Thermo spectrophotometer, Nicolet IR 200, with KBr) in order to determine the functional groups that take part in the biosorption process. Then, FTIR spectra were recorded between 4000 and $400 \mathrm{~cm}^{-1}$.

\subsubsection{Morphological Characteristics of the $U$. lactuca Surface}

The morphological characterization and microanalysis of the algal biomass at different steps of the biosorption and activation process were carried out using scanning electron microscopy (SEM), equipped with an energy-dispersive X-ray spectroscopy (EDX) unit, in order to deduce any change in the modified biomass compared to raw algae. SEM and EDX were performed on a JEOL JEM-2100 electron microscope.

\subsection{Study of the Biosorption Process}

To evaluate the biosorption capacities of MB by the raw and modified $U$. lactuca species, a series of batch biosorption experiments was carried out. Note that the various parameters affecting the biosorption, namely $\mathrm{pH}$, mass of adsorbent, and contact time, have already been confirmed in previous works, including El Jamal and Ncibi [37].

In a $100 \mathrm{~mL}$ brown glass bottle, four doses of modified or unmodified $U$. lactuca $(0.13$, $0.2,0.26$, or $0.5 \mathrm{~g}$ ) were added to $50 \mathrm{~mL}$ of MB solutions of $5 \times 10^{-5} \mathrm{~mol} \mathrm{~L}^{-1}$ and stirred at $200 \mathrm{rpm}$ at $25 \pm 1{ }^{\circ} \mathrm{C}$ for $2 \mathrm{~h}$, which was sufficient to reach equilibrium, in order to draw the biosorption isotherm and deduce the $\mathrm{q}_{\max }$ (constants that are related to the maximum adsorption capacity). The effect of $\mathrm{pH}$ on the biosorption rate of $\mathrm{MB}$ on the different biomasses of $U$. lactuca was studied over a wide $\mathrm{pH}$ range (2 to 10). For the different series, the $\mathrm{pH}$ of the studied solution was adjusted to the desired values by the addition of $0.1 \mathrm{M}$ $\mathrm{HCl} / \mathrm{NaOH}$, and the mixtures were stirred for $120 \mathrm{~min}$.

After $120 \mathrm{~min}$ of stirring, the various series were centrifuged at $5000 \mathrm{rpm}$ for $5 \mathrm{~min}$ and then decanted. The decanted solution was analyzed at $664 \mathrm{~nm}$, the maximum wavelength of MB, using a UV-Visible double beam spectrophotometer (Specord 200, Analytical Jena, Jena, Germany). The isothermal experiments were carried out in triplicate. The kinetic study was similarly studied by preparing several samples under the same conditions ( $1 \mathrm{mg}$ of activated and nonactivated biomass, $50 \mathrm{~mL}$ of $\mathrm{MB}$ of fixed concentration $\left.5 \times 10^{-5} \mathrm{~mol} \cdot \mathrm{L}^{-1}\right)$. Then, $2 \mathrm{~mL}$ was secluded as a function of time to determine the biosorption rate constant and the order of biosorption.

The amounts of MB adsorbed per unit mass of $U$. lactuca at equilibrium (qe) or at time $t$ (qt) were calculated according to the following relationships (Equations (3) and (4)).

$$
\begin{gathered}
\mathrm{qe}=\left(\mathrm{C}_{0}-\mathrm{C}_{\mathrm{e}}\right) \frac{\mathrm{V}}{\mathrm{m}} \text { Adsorbed } \mathrm{MB} \text { at equilibrium } \\
\mathrm{qt}=\left(\mathrm{C}_{0}-\mathrm{C}_{\mathrm{t}}\right) \frac{\mathrm{V}}{\mathrm{m}} \text { Adsorbed } \mathrm{MB} \text { at time } \mathrm{t} \\
\text { Removal\% } \frac{\mathrm{C}_{0}-\mathrm{C}_{\mathrm{e}}}{\mathrm{C}_{0}} * 100 \text { Removal } \% \text { of } \mathrm{MB}
\end{gathered}
$$

where $\mathrm{C}_{0}$ and $\mathrm{Ce}$ are the initial and equilibrium concentrations of $\mathrm{MB}\left(\mathrm{mg} \cdot \mathrm{L}^{-1}\right)$, respectively; $\mathrm{Ct}$ is a concentration of $\mathrm{MB}$ at time $t ; \mathrm{V}$ is the volume of the adsorbate $\mathrm{MB}$ solution $(\mathrm{L}) ; \mathrm{m}$ is the quantity of adsorbent used $(\mathrm{g})$. The percentage of adsorbate elimination (MB) was calculated using Equation (5).

\subsection{Kinetic Study of Biosorption}

Between the adsorbate in the liquid phase and the adsorbent in the solid state, a thermodynamic equilibrium is reached with a speed that depends not only on the speed at which the molecules of the adsorbate diffuse into the adsorbent but also on the adsorbentadsorbate interaction, which can be chemical or physical in nature. 
The analysis of the temporal biosorption of an impurity on an adsorbent consists of testing the influence of the contact time on its retention. In this context, we applied four models of the kinetic study of the U. lactuca-MB pair in order to deduce the mechanism of the $\mathrm{MB}$ biosorption dynamics on the different modified and unmodified algae biomasses. The models studied are the pseudo-first-order model (Equation (6)) [38], the chemisorption's pseudo-second-order model (Equation (7)) [39], the intraparticle diffusion model (Equation (8)) [40], and the Elovich kinetic model (Equation (9)) [41].

$$
\begin{gathered}
\log (q e-q t)=\log (q e)-K_{1} \times t / 2.303 \text { Pseudo-first-Order } \\
t / q t=1 /\left(K_{2} q_{e}{ }^{2}\right)+(1 / q e) t \text { Pseudo-second-order } \\
q t=K_{i n t} t^{1 / 2}+C \text { Intraparticle diffusion } \\
q t=1 / \beta \ln (\alpha \beta)+1 / \beta \operatorname{lnt} \text { Elovich kinetic }
\end{gathered}
$$

where $K_{1}, K_{2}$, and $K_{\text {int }}$ are the rate constants of the biosorption kinetics of the pseudofirst order $\left(\mathrm{min}^{-1}\right)$, pseudo-second order $\left(\mathrm{g} \cdot \mathrm{mg}^{-1} \cdot \mathrm{min}^{-1}\right)$, and intraparticle diffusion $\left(\mathrm{mg} \cdot \mathrm{g}^{-1} \cdot \mathrm{min}^{-1 / 2}\right)$, respectively; $\mathrm{qt}$ and qe are successively the biosorption capacities at time $\mathrm{t}$ and at equilibrium $\left(\mathrm{mg} \cdot \mathrm{g}^{-1}\right)$, respectively; $\mathrm{C}$ is the value of the intercept, which explains the thickness of the boundary layer; $\alpha$ is the initial biosorption rate in $\left(\mathrm{mg} \cdot \mathrm{g}^{-1} \cdot \mathrm{min}^{-1}\right) ; \beta$ is a constant related to the external surface and to the activation energy of chemisorption (in.g. $\mathrm{mg}^{-1}$ ).

\subsection{Biosorption Isotherm}

The objective of this study was to visualize the nature of the $U$. lactuca-MB interaction in order to validate models and find the optimal conditions that allow for the interpretation and prediction of MB biosorption data [42]. Note that there are several theories of isotherms, and two important isotherms were used during this study in order to determine the equilibrium parameters: Langmuir and Freundlich.

The Langmuir isotherm, being a monolayer biosorption of the adsorbate on a homogeneous surface of adsorbent, does not have transmigration of the adsorbate on the adsorbent $[43,44]$. The Langmuir equation is in the linearized form presented by Equation (10).

$$
\begin{gathered}
\text { Ce } / \mathrm{qe}=1 /\left(\mathrm{q}_{\max } \mathrm{K}_{\mathrm{L}}\right)+\mathrm{Ce} / \mathrm{q}_{\max } \text { Langmuir equation } \\
\mathrm{R}_{\mathrm{L}}=1 /\left(1+\mathrm{K}_{\mathrm{L}} \mathrm{C}_{\mathrm{i}}\right) \text { Separation factor } \\
\log (\mathrm{qe})=\log \left(\mathrm{K}_{\mathrm{F}}\right)+1 / \mathrm{n} \log (\mathrm{Ce}) \text { Freundlich isotherm }
\end{gathered}
$$

where $\mathrm{Ce}$ is the equilibrium concentration $\left(\mathrm{mg}^{-1} \mathrm{~g}^{-1}\right)$, qe is the adsorption capacity at equilibrium $\left(\mathrm{mg} \cdot \mathrm{g}^{-1}\right), \mathrm{q}_{\max }\left(\mathrm{mg} \cdot \mathrm{g}^{-1}\right)$ is the maximum monolayer coverage capacity, and $\mathrm{K}_{\mathrm{L}}$ is the Langmuir isotherm constant or the biosorption rate $\left(\mathrm{L} \cdot \mathrm{mg}^{-1}\right.$ or $\left.\mathrm{L} \cdot \mathrm{mol}^{-1}\right)$. By wearing the curve $\mathrm{Ce} / \mathrm{qe}$ as a function of $\mathrm{Ce}$, a straight line was obtained; $\mathrm{q}_{\max }$ and $\mathrm{q}_{\max } \mathrm{k}_{\mathrm{L}}$ could be estimated from the slope and the intersections, respectively.

One of the essential characteristics of the Langmuir isotherm can be expressed by a separation factor; $\mathrm{R}_{\mathrm{L}}$ values indicate the type of isotherm, which is defined (Equation (11)) by Weber and Chakravorti [43], where $C_{i}$ is the initial concentration of dye $\left(\mathrm{mg} \cdot \mathrm{L}^{-1}\right)$. The value of $R_{L}$ indicates whether an isotherm is irreversible $\left(R_{L}=0\right)$, favorable $\left(0<R_{L}<1\right)$, linear $\left(R_{L}=1\right)$, or unfavorable $\left(R_{L}>1\right)$.

The Freundlich isotherm is determined by Equation (12), where the Freundlich constant $\mathrm{K}_{\mathrm{F}}\left(\mathrm{mg} \cdot \mathrm{g}^{-1}\right)(\mathrm{L} / \mathrm{mg})^{1 / \mathrm{n}}$ establishes the adsorption capacity of basic dye (MB) for a unit equilibrium concentration, $\mathrm{n}$ is the biosorption intensity, and its inverse $1 / \mathrm{n}$ is an empirical parameter linked to the rate of biosorption or to the heterogeneity of the surface of the adsorbent, which predicts the favorability of the non-biosorption [44]. The biosorption is considered to be favorable in the case where the value of $1 / \mathrm{n}$ is between 0 and 1 . The latter can take the following three ranges: $1 / n=1$ indicates that the distribution between the adsorbent and adsorbate is independent of the concentration; the most common range 
is $1 / \mathrm{n}<1$, which indicates that the dye is favorably adsorbed by the activated carbons; and $1 / \mathrm{n}>1$ indicates that biosorption is a favorable physical process, which gives greater importance to the rigid interaction between adsorbate molecules [45].

\section{Results and Discussion}

\subsection{Specific Surface Area of Algal Biomass}

The surface characteristics of the untreated and treated dry adsorbents used in this study are shown in Table 1.

According to the results in Table 1, different treatments permitted the development of surface micropores on the materials because treated adsorbents (UL-H, UL-OH, and UL-T) and the water insoluble substance (UL-WIS) have a higher specific surface area than the untreated adsorbent (UL-NA). The increase in the specific surface area testifies to the important modifications that took place at the level of the porous structure of these materials. These modifications are more favored in the basic treated biomass, followed by the water insoluble substance, whereas the acid treatment and the carbonized process produce less porous materials, showing a weak biosorption. Thus, UL-OH and UL-WIS have more anionic sites than UL-H, UL-T, and UL-NA, which attracted the cationic dye [46].

\subsection{Functional Group Alterations Before and After Biosorption}

The results of the FTIR spectral analysis are illustrated in Figures $2-5$ and Table 2 for the activated and nonactivated dried $U$. lactuca before and after the dye biosorption. The results give the main information on the functional groups on the surface of different treated and untreated biomasses, before and after biosorption of $\mathrm{MB}$, in order to detect the possible interactions between the dyes and the functional groups of the biomasses.

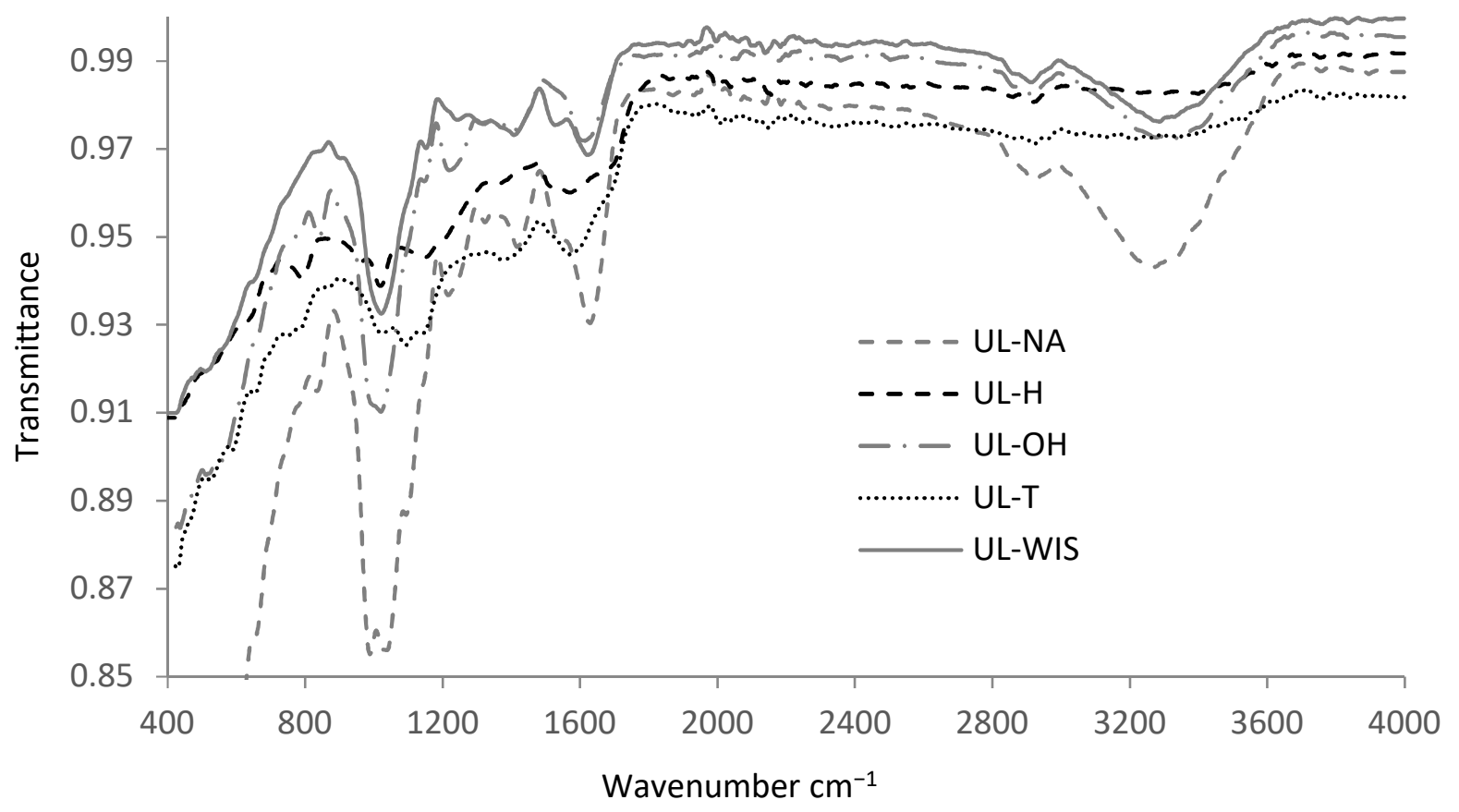

Figure 2. IR Spectra of the untreated (UL-NA), UL-WIS, and treated (UL-H, UL-OH, UL-T) dry U. lactuca before biosorption. 


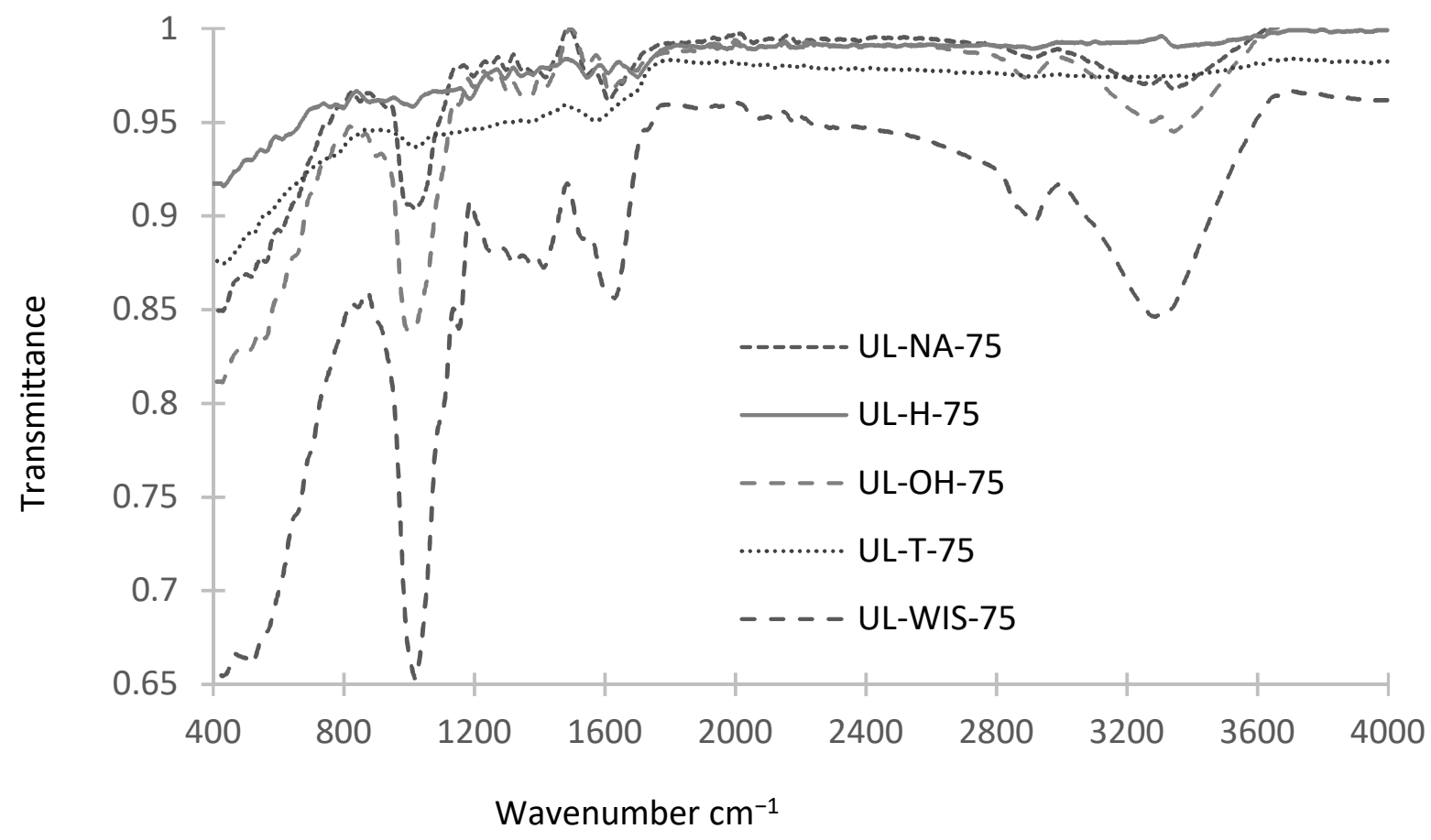

Figure 3. IR Spectra of the untreated (UL-NA), UL-WIS, and treated (UL-H, UL-OH, UL-T) dry U. lactuca after 75 min of contact with methylene blue (MB).

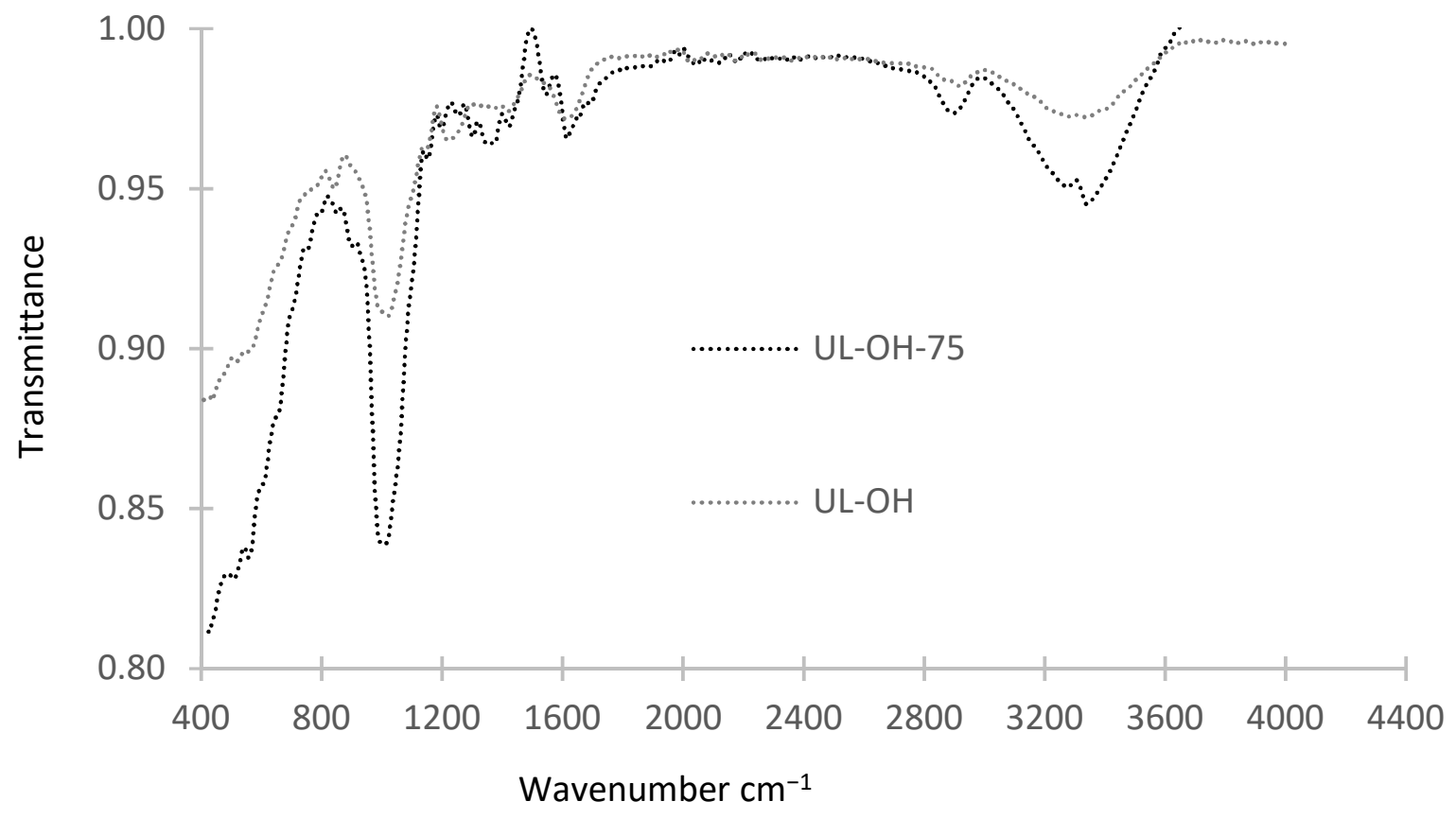

Figure 4. IR spectra of the base-treated (UL-OH) dry U. lactuca before and after 75 min of contact with MB. 


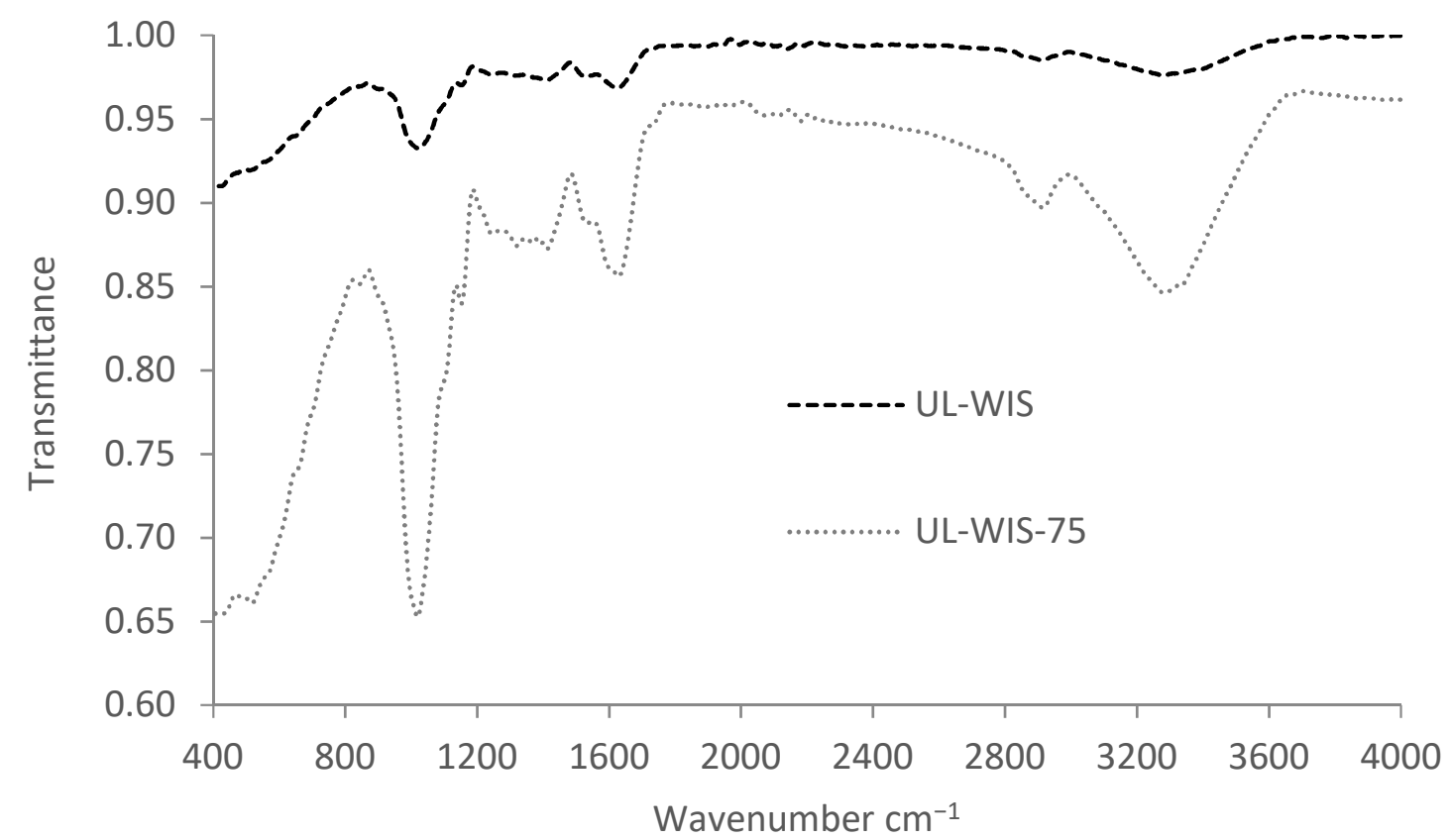

Figure 5. IR spectra of the water insoluble substance (UL-WIS) dry U. lactuca before and after 75 min of contact with MB.

The infrared spectrum of nontreated dried algae (UL-NA: control) (Figure 2) gives the number of biosorption peaks of untreated UL-NA biomass, which shows its complex nature. Thus, the spectrum shows that several functional groups, such as $-\mathrm{OH}$ and $-\mathrm{NH}$ at $3307 \mathrm{~cm}^{-1}$, correspond to the alcohols, phenols, and carboxylic acids of cellulose and lignin, and to proteins, respectively [47]. Thus, biosorption of MB dye on algal biomass is attributed to the phenolic and acidic groups. In addition, two small peaks correspond to the aliphatic $-\mathrm{CH}$ in the methyl group of $-\mathrm{CH}_{2}$ in lipids at $2958 \mathrm{~cm}^{-1}$ and $2895 \mathrm{~cm}^{-1}$. Aromatic $\mathrm{C}=\mathrm{C}$ and $\mathrm{C}=\mathrm{O}$ at $1638 \mathrm{~cm}^{-1}$ correspond to protein amide $\mathrm{I}$; the secondary amine group at $1579 \mathrm{~cm}^{-1}$ corresponds to protein amide II; N-H bending at $1430 \mathrm{~cm}^{-1},-\mathrm{CH}_{3}$ bending at $1369 \mathrm{~cm}^{-1},-\mathrm{SO}_{3}$ stretching $/ \mathrm{P}=\mathrm{O}$ at $1236 \mathrm{~cm}^{-1}, \mathrm{C}-\mathrm{O}-\mathrm{C}$ groups of polysaccharide at $1101 \mathrm{~cm}^{-1}$, and $\mathrm{C}-\mathrm{O}-\mathrm{H}$ groups of polysaccharide at $1048 \mathrm{~cm}^{-1}$ and $1050 \mathrm{~cm}^{-1}$ show that it is a Homogalacturonan-type polysaccharide (HG) [48]. All of the peaks indicate the presence of polysaccharides, amino acids, esters, and pectin, as confirmed by previous studies [49-51]. However, for the dry algae treated chemically by carbonization or solvent, we noticed a more complicated spectrum, with less intense bands and the appearance of a multitude of absorption bands in the fields of analysis. The broad band around $3307 \mathrm{~cm}^{-1}$ decreased considerably, but the peaks at $1638 \mathrm{~cm}^{-1}$ and $1048 \mathrm{~cm}^{-1}$ are quite clear for ULWIS and UL-OH, and in UL-T and UL-H they correspond to the vibrations of the amides and the $\mathrm{C}-\mathrm{O}$ bonds of the alcohols present in the phenols. Beyond $1000 \mathrm{~cm}^{-1}$, several peaks appear in the vicinity of 900 and $850 \mathrm{~cm}^{-1}$ and may correspond to deformations out of the plane of $\mathrm{C}-\mathrm{O}-\mathrm{H}$ bonds in carboxylic acids and swaying vibrations of amines. 
Table 2. Assignment of bands found in FTIR spectra of different adsorbent UL-NA, UL-WIS, UL-OH, UL-H, and UL-T and the MB adsorbate.

\begin{tabular}{|c|c|c|c|c|c|c|c|c|c|c|c|c|}
\hline \multirow{3}{*}{1 Band Assignment from the Literature } & \multicolumn{10}{|c|}{ Main Peak $\left(\mathrm{cm}^{-1}\right)$ from Adsorbent (U. lactuca) } & \multirow{2}{*}{\multicolumn{2}{|c|}{$\begin{array}{c}\text { Main Peak }\left(\mathrm{cm}^{-1}\right) \text { from Adsorbate (MB) } \\
\text { MB }\end{array}$}} \\
\hline & \multicolumn{2}{|c|}{ UL-NA } & \multicolumn{2}{|c|}{ UL-WIS } & \multicolumn{2}{|c|}{ UL-OH } & \multicolumn{2}{|c|}{ UL-H } & \multicolumn{2}{|c|}{ UL-T } & & \\
\hline & Bef. & Aft. & Bef. & Aft. & Bef. & Aft. & Bef. & Aft. & Bef. & Aft. & $\begin{array}{l}\text { Functional Groups } \\
\text { of MB }\end{array}$ & $\begin{array}{c}\Lambda \mathrm{cm}^{-1} \text { of FT-IR } \\
\text { Spectrum }\end{array}$ \\
\hline $\begin{array}{l}\text { Water } \mathrm{v}(\mathrm{O}-\mathrm{H}) \text { stretching protein } \\
\mathrm{v}(\mathrm{N}-\mathrm{H}) \text { stretching }\end{array}$ & 3307 & $\begin{array}{l}3389 \\
3324\end{array}$ & 3350 & $\begin{array}{l}3332 \\
3360\end{array}$ & 3350 & $\begin{array}{l}3381 \\
3317\end{array}$ & 3434 & 3399 & 3352 & - & $\begin{array}{l}-\mathrm{NH} /-\mathrm{OH} \text { stretching } \\
\text { vibration absorbance }\end{array}$ & 3410 \\
\hline $\begin{array}{l}\text { Lipid-carbohydrate mainly vas }\left(\mathrm{CH}_{2}\right) \text { and vs. } \\
(\mathrm{CH} 2) \text { stretching }\end{array}$ & $\begin{array}{l}2958 \\
2895\end{array}$ & $\begin{array}{c}2948 \\
-\end{array}$ & $\begin{array}{l}2940 \\
2895\end{array}$ & $\begin{array}{l}2934 \\
2891\end{array}$ & $\begin{array}{l}2952 \\
2895\end{array}$ & $\begin{array}{l}2938 \\
2230\end{array}$ & $\begin{array}{l}2938 \\
2895\end{array}$ & $\begin{array}{l}2958 \\
2240\end{array}$ & $\begin{array}{l}2962 \\
2895\end{array}$ & $\begin{array}{c}2954 \\
-\end{array}$ & $\begin{array}{l}\text { symmetrical stretching } \\
\mathrm{C}-\mathrm{H} \text { of }-\mathrm{CH}_{2} \text { peak }\end{array}$ & 2928 \\
\hline $\begin{array}{l}\text { Protein amide II band mainly } \delta(\mathrm{NH}) \text { bending } \\
\text { and } \mathrm{v}(\mathrm{C}-\mathrm{N}) \text { stretching }\end{array}$ & 1579 & 1589 & 1571 & 1573 & - & 1589 & 1565 & 1560 & - & - & $\begin{array}{l}\text { stretching band of } \mathrm{C}-\mathrm{O} \text {, } \\
\mathrm{C}-\mathrm{N} \text { from the amide II }\end{array}$ & 1572 \\
\hline $\begin{array}{l}\text { Protein } \delta \text { as }(\mathrm{CH} 2) \text { and } \delta \text { as }\left(\mathrm{CH}_{3}\right) \text { bending of } \\
\text { methyl, Lipid } \delta \text { as }(\mathrm{CH} 2) \text { bending of methyl }\end{array}$ & 1430 & 1434 & 1428 & 1428 & 1436 & 1436 & 1414 & 1462 & 1426 & 1434 & $\begin{array}{l}\text { symmetrical stretching } \\
\text { peak of carboxyl } \\
(-\mathrm{COOH})\end{array}$ & 1442 \\
\hline $\begin{array}{c}\text { Protein } \delta \mathrm{s}(\mathrm{CH} 2) \text { and } \delta \mathrm{s}\left(\mathrm{CH}_{3}\right) \text { bending of methyl } \\
\text { Carboxylic Acid vs. }(\mathrm{C}-\mathrm{O}) \text { of } \mathrm{COO} \text { - groups of } \\
\text { carboxylates Lipid } \delta \mathrm{s}\left(\mathrm{N}\left(\mathrm{CH}_{3}\right) 3\right) \text { bending of } \\
\text { methyl }\end{array}$ & 1369 & 1342 & 1358 & 1363 & 1368 & 1383 & 1389 & 1342 & - & 1395 & - & \\
\hline $\begin{array}{c}\text { Nucleic acid (other phosphate containing } \\
\text { compounds) vas }(>\mathrm{P}=\mathrm{O} \text { ) stretching of } \\
\text { phosphodiesters }\end{array}$ & 1236 & $\begin{array}{l}1294 \\
1244\end{array}$ & 1291 & 1285 & 1248 & $\begin{array}{l}1248 \\
1300\end{array}$ & - & 1197 & - & 1244 & - & \\
\hline Carbohydrate v(C-O-C) of Polysaccharides & 1151 & - & 1159 & - & 1159 & - & 1163 & - & 1154 & - & $\begin{array}{l}\text { bending band of } \mathrm{N}-\mathrm{H} \\
\text { and C-N from the amide } \\
\text { III band }\end{array}$ & 1140 \\
\hline \multirow[t]{2}{*}{$\begin{array}{l}\text { Sulfate groups as } \mathrm{S}=\mathrm{O}, \mathrm{C}-\mathrm{O}-\mathrm{S} \text { and } \mathrm{v}(\mathrm{C}-\mathrm{S}-\mathrm{C}) \text { of } \\
\text { sulphated polysaccharides }\end{array}$} & $\begin{array}{l}1048 \\
1050\end{array}$ & $\begin{array}{l}1030 \\
1046\end{array}$ & 1032 & 1032 & 1030 & 1026 & $\begin{array}{c}1026 \\
995\end{array}$ & 1026 & 1067 & 1040 & $\begin{array}{l}\text { Vibrational bands of } \\
\text { C-S-C }\end{array}$ & $(615-625,1095)$ \\
\hline & 848 & 895 & 893 & 901 & 850 & $\begin{array}{l}942 \\
889\end{array}$ & 801 & $\begin{array}{l}926 \\
810\end{array}$ & 863 & 801 & $\begin{array}{l}\text { bending band of } \mathrm{N}-\mathrm{H} \\
\text { and C-N from the amide } \\
\text { III band }\end{array}$ & 854 \\
\hline
\end{tabular}


The MB spectrum shows several intense peaks at $3410 \mathrm{~cm}^{-1}$ (attributed to $-\mathrm{NH} /$ $\mathrm{OH})$ that correspond to the absorbance of stretch vibration, while the peak at $2928 \mathrm{~cm}^{-1}$ corresponds to the symmetrical stretch $\mathrm{CH}$ of the peak $-\mathrm{CH} 2$. The bands at $1572 \mathrm{~cm}^{-1}$ and $1442 \mathrm{~cm}^{-1}$ belong to the stretch bands of CO and CN of amide II and to the symmetrical stretching peak of carboxyl (-COOH), respectively. The intense peaks at $1140 \mathrm{~cm}^{-1}$ and $854 \mathrm{~cm}^{-1}$ correspond to the flexion band of NH and CN of amide III [52]. Figures 3-5 show the spectra of (UL-NA-75, UL-WIS-75, UL-H-75, UL-OH-75, and UL-T-75) after biosorption. The peaks around $3307-3399 \mathrm{~cm}^{-1}$ (Table 2) with respect to $\mathrm{NH} / \mathrm{OH}$ absorbance decreased, and a new peak appeared at $3317-3360 \mathrm{~cm}^{-1}$ as a reinforcement of the $\mathrm{CH}$ asymmetric vibration peaks of $\mathrm{CH}_{3}$. This change most likely corresponds to the adsorption of methylene blue on the adsorbent. This means that these two functional groups participate in the MB adsorption process. In addition, the IR spectrum shows the disappearance of absorbance at 1151-1161 $\mathrm{cm}^{-1}$, corresponding to $\mathrm{v}(\mathrm{C}-\mathrm{O}-\mathrm{C})$ of carbohydrates.

The strength of the adsorption peaks at $1579-1565 \mathrm{~cm}^{-1}$ corresponding to protein amide II band, mainly $\delta(\mathrm{NH})$ bending and $\mathrm{v}(\mathrm{C}-\mathrm{N})$ stretching, were absent in UL-OH and UL-T because of the denaturation of proteins in the presence of the basic medium and at high temperature [48]. Interestingly, the same band appeared strongly in UL-OH after adsorption of $\mathrm{MB}$, which might be attributed to the hydrogen bond between $\mathrm{N}$ in $\mathrm{MB}$ and $\mathrm{H}$ of $\mathrm{OH}$ in UL-OH surface [53]. Furthermore, this band shifted and obviously decreased in the different treatments.

The presence and absence of $1579-1565 \mathrm{~cm}^{-1}$ band in UL-OH and UL-T before and after MB adsorption indicate that hydrogen bonds participate in the adsorption process of $\mathrm{MB}$ on the UL-OH surface, while the electrostatic attractions contribute to the adsorption process of MB on the UL-T surface.

Regarding the acidic activation (UL-H), acid removes the hydroxyl group in the form of $\mathrm{H}_{2} \mathrm{O}$ molecules, resulting in negative oxygen functional groups on the activated surface, which would reduce the electrons from $\Pi$ bond, affecting the efficiency of $\Pi$ - $\Pi$ between $\mathrm{C}=\mathrm{C}$ or the benzyne ring of $\mathrm{MB}$ and the activated surface [54].

These results prove that the $(-\mathrm{COOH}),(-\mathrm{NH} 2)$, and $(\mathrm{OH})$ groups are responsible in general for the chemical and electrostatic adsorption process of $\mathrm{MB}$ on the biomass surface $[47,53,55]$.

\subsection{SEM Analysis}

Scanning electron micrographs were applied to different $U$. lactuca biomasses in order to prove external textures, morphology features, and forms. The texture of the treated and untreated surface of dry algae before and after biosorption was observed by SEM imaging (Figure 6). The external morphology of the dry UL-NA (raw U. lactuca) exhibits a cave-like surface, which is uneven and has rough clumps and not many pores. The surface of the algae pits is moderately smooth, with fewer cracks and voids than activated carbon prepared by different chemical reagents and by carbonization treatments, which cause an irregular and rough surface that plays an important role in the biosorption of MB (Figure 6a). This is due to the chemical or physical loss of organic compounds during the activation process, confirmed by mass loss $48.0 \%, 58.0 \%, 58.4 \%$, and $64.0 \%$ of UL-WIS, UL-H, UL-T, and UL-OH biomass, respectively. It is worth mentioning that the treatment of highest mass loss (UL-OH) has an obvious irregular and rough surface compared to the treatment of less mass loss (UL-WIS), which has relatively smooth surface (Table S1, Figure 6a). This reveals side effects, such as the degradation of cellular tissue, which can produce such a surface topology $[55,56]$. 

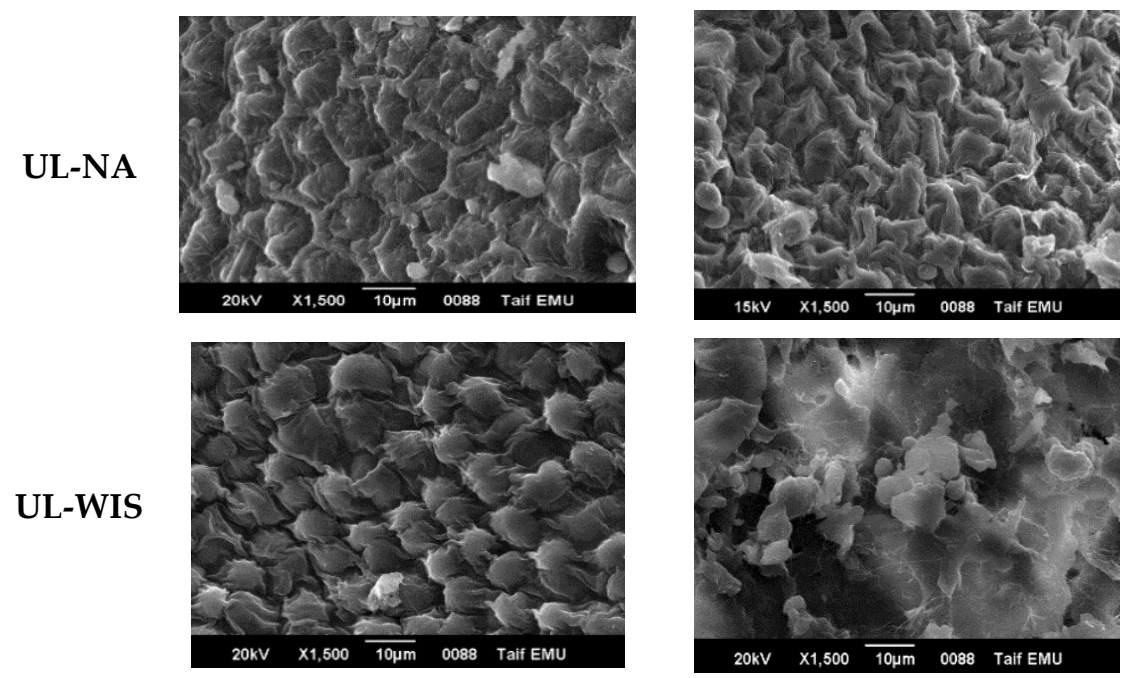

UL-WIS
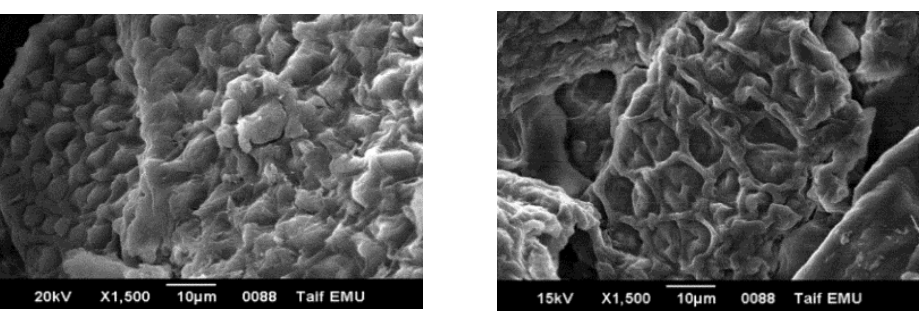

UL-OH
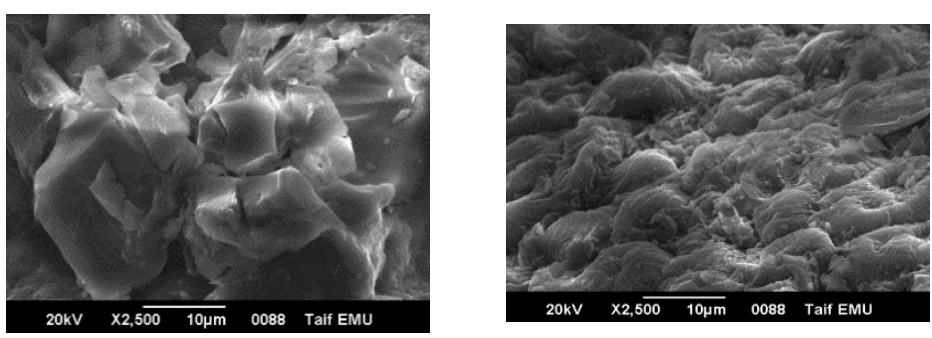

UL-H

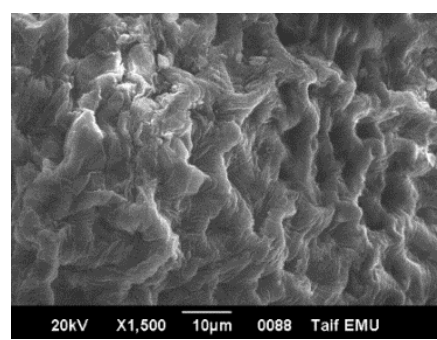

Before biosorption (a)

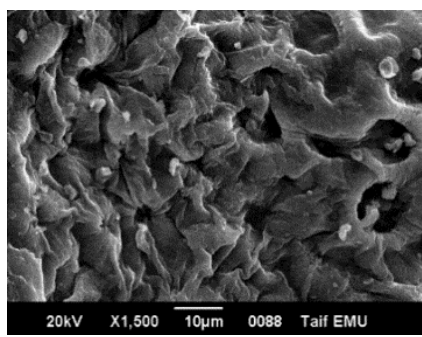

75 min after biosorption $(b)$

Figure 6. SEM micrograph of raw dry U. lactuca (UL-NA), UL-WIS, and different treated U. lactuca (UL-OH, UL-H, UL-T) before (a) and after (b) 75 min of contact with MB, at 1500 magnification.

However, this surface modification was irregular in structure and more porous in UL-OH and UL-WIS than UL-H and UL-T. However, the acid treatment (UL-H) and that using carbonization (UL-T) were moderately smooth, with fewer cracks and voids than all other carbon compounds activated by alkaline treatment (UL-OH) and the water insoluble substance (UL-WIS). Therefore, the large surface area explains the better adsorption capacity.

After the biosorption of dye (Figure 6b), a change in bark structure is observed; it appears to have a rough pore surface because it is partially covered by dye molecules, as demonstrated by Annadurai et al. [57]. 
Various elements were identified from the biomass before and after the biosorption utilizing EDX analysis. The peaks of carbon, oxygen, and sulfur were recorded in the EDX spectrum (Table 3) [58].

Table 3. EDX results for the elemental composition element of untreated (UL-NA), UL-WIS, and treated (UL-H, UL-OH, UL-T) dry U. lactuca before and after 75 min of contact with methylene blue.

\begin{tabular}{ccccccccccc}
\hline & \multicolumn{2}{c}{ UL-NA } & \multicolumn{2}{c}{ UL-WIS } & \multicolumn{2}{c}{ UL-OH } & \multicolumn{2}{c}{ UL-H } & \multicolumn{2}{c}{ UL-T } \\
\hline & Before & After & Before & After & Before & After & Before & After & Before & After \\
\hline $\mathrm{C}$ & 46.53 & 47.35 & 25.84 & 57.69 & 48.35 & 51.61 & 64.35 & 71.79 & 71.28 & 71.65 \\
$\mathrm{O}$ & 46.95 & 48.89 & 3.65 & 41.13 & 48.81 & 47.15 & 34.68 & 26.38 & 28.11 & 26.42 \\
$\mathrm{Na}$ & 0.75 & - & - & - & 0.79 & - & 0.41 & - & - & - \\
$\mathrm{Mg}$ & 2.36 & 1.90 & 0.02 & 0.55 & 0.82 & 0.56 & - & 0.34 & 0.33 & 0.36 \\
$\mathrm{~S}$ & 1.77 & 1.44 & - & 0.25 & 1.00 & 0.47 & 0.28 & 0.37 & 0.14 & 0.28 \\
$\mathrm{Cl}$ & 0.06 & - & - & - & - & - & - & - & - & - \\
$\mathrm{K}$ & 0.28 & - & - & - & - & - & - & - & - & - \\
$\mathrm{Ca}$ & 0.43 & 0,42 & 0.02 & 0.37 & 0.23 & 0.21 & 0.27 & 0.57 & 0.15 & 1.04 \\
\hline
\end{tabular}

The values represent atom $\%$ (normalized by total atom $\%$ ).

However, the chemical composition of treated and nontreated carbon derived from dried $U$. lactuca before and after biosorption showed that the amount of $\mathrm{C}$ and $\mathrm{O}$ increased in all adsorbents, while that of $\mathrm{Mg}, \mathrm{Cl}, \mathrm{K}, \mathrm{Ca}, \mathrm{S}$, and $\mathrm{Na}$ was found to decrease in UL-OH and UL-NA [59] and increase in UL-H, UL-WIS, and UL-T. That is, the salts that are present at the different biomasses are ionized during the adsorption operation. Therefore, their concentrations decrease, but the concentration of carbon and oxygen increases. This happens when MB interacts chemically with surface content; however, when the interaction becomes ionic exchange, the density of ions increases. This has been confirmed by [31,53,59].

Regarding the $\mathrm{S}$ amount, it can be clearly observed that the $\mathrm{S}$ amount decreases in UL-OH and UL-NA, while it increases in UL-WIS, UL-H, and UL-T. To further confirm adsorption of $\mathrm{MB}$ by different untreated and treated $U$. lactuca, SEM-EDX analyses were conducted to compare chemical composition (see Figure S2 in Supplementary material). According to these analyses, carbon and oxygen peaks are more dominant, followed by magnesium and sulfur peaks and finally calcium, potassium, sodium, and chloride peaks.

However, after MB adsorption, the main element contents (carbon and oxygen) were notably increased, whereas the content of sulfur decreased in UL-OH and UL-NA and increased in UL-WIS, UL-H and UL-T, which suggests that sulfur plays a role in the adsorption process via electrostatic between various sulfuric functional groups in biomass and MB.

Based on IR analysis, the cell wall of different biomasses before the adsorption process (Table 2, Figures 2-5) clarified that the presence of band at (1026-1067 $\left.\mathrm{cm}^{-1}\right)$ corresponds to functional group (CSC) specific sulfated polysaccharides [60] and the vibratory band of the $=\mathrm{N}+\left(\mathrm{CH}_{3}\right) 2$ at $\left(1614-1697 \mathrm{~cm}^{-1}\right)$ is specific to protein amide I. These former two bands are functional groups existing in the structure of MB [61]. On the other hand, IR spectra after adsorption revealed a very noticeable increase in the adsorption band of (CSC) on the cell surface of UL-OH and UL-WIS and the disappearance of the vibratory band of $=\mathrm{N}+\left(\mathrm{CH}_{3}\right) 2$ in the other absorbents (UL-H, UL-NA and UL-T), which confirms the involvement of these two functional groups in the elimination of dye, which in turn leads to the increase or decrease of the sulfur amount in the biomass surface.

However, the main functional groups existing on the majority of treated and untreated U. lactuca biomasses are $-\mathrm{OH},-\mathrm{C}=\mathrm{O},-\mathrm{NH} 2$ (amide) and $-\mathrm{SO} 3$. These results explain that $\mathrm{MB}$ (positive charge) interacts by means of these groups $(-\mathrm{OH},-\mathrm{C}=\mathrm{O},-\mathrm{NH} 2$ (amide) and -SO3) existing on the surface of the biomass through oxygen bonds for $\mathrm{C}=\mathrm{O},-\mathrm{NH} 2$ (UL-T, UL-H, and UL-NA) and hydrogen bonds for -SO3 (UL-OH and UL-WIS), explaining the increase and the successive decrease of sulfur. Thermodynamic explanation suggests very probably that the binding energies were the result of the physisorption process during the 
removal of cationic MB dyes, which corresponds well to the formation of an intermolecular electrostatic bond at the solid/liquid interface [62].

It is worth mentioning that EDX data show an inverse relationship between the amount of sulfur versus magnesium along with calcium, which sheds light on an interesting phenomena: when sulfur contributes to the adsorption process, a decrease in the sulfur amount is associated with an increase of magnesium and calcium amount, as shown in UL-NA and UL-OH (Table 3) and vice versa as clearly seen in UL-WIS, UL-H, and UL-T (Table 3).

The results suggest that the most suitable mechanism in the biosorption process of the adsorbents UL-NA and UL-OH on MB is by chemical bonds rather than by ion exchange [53,59]; thus, in UL-WIS, UL-H, and UL-T, the mechanism in the biosorption process was probably the ion exchange type.

\subsection{Contact Time}

The inspection of MB biosorption on biomass obviously requires estimation of the contact time, defined as being the time suitable for the saturation of the adsorbent surface that corresponds to the equilibrium time leading to the end of the biosorption mechanism. In this trial, we followed a simple "batch method", which consists of putting $16 \mathrm{mg} / \mathrm{L}$ of MB in contact separately in the presence of two concentrations (low concentration $20 \mathrm{mg} \mathrm{L}^{-1}$ and high concentration $6 \mathrm{~g} \mathrm{~L}^{-1}$ ) of each biomass treated from dry $U$. lactuca. In this work, a UV-Visible spectrophotometer analysis was used to assess the residual concentrations of MB during sampling at different contact times. However, the estimation of the equilibrium time serves to describe the biosorption isotherms essential for the determination of the maximum adsorption capacity and for the visualization of the biosorption nature of the $\mathrm{MB}$ carried out in single or multiple layers. The results of this study show that the best contact time was $75 \mathrm{~min}$ for most but not all treatments at low and high concentrations (Figure 7a,b), which corresponds to a sufficient removal of the dye. At $75 \mathrm{~min}$, all treatments at low concentration $(20 \mathrm{mg} / \mathrm{L}$ ) removed $\mathrm{MB}$ from as low as $5 \%$ (UL-T) to as high as $89 \%$ (UL-OH) (Figure $7 \mathrm{a}$ ). For the high concentration, $6 \mathrm{~g} / \mathrm{L}$, the extracts of the dry algae eliminated $75-98 \%$ of MB at $75 \mathrm{~min}$ (Figure $7 \mathrm{~b}$ ). Note that extending the contact time beyond 75 min (120 min) does not lead to significant progress in the removal proportion of MB for most $U$. lactuca adsorbents at either a low or high concentration. This justifies using this contact time $(75 \mathrm{~min})$ for other biosorption experiments. It is worth mentioning that, at 75 min, the amount of $U$. lactuca in MB solution significantly affected the removal percentage of MB by UL-H and UL-T, as seen in Figure 7a,b. These two treatments removed only $5 \%$ at low concentration (Figure $7 \mathrm{a}$ ) but removed $98 \%$ at high concentration (Figure $7 \mathrm{~b}$ ), which clearly demonstrates the effect of algal biomass on the removal percentage for all treatments, especially for UL-H and UL-T. It can be clearly observed that the increase in contact time for UL-H and UL-T at low algal dose $\left(20 \mathrm{mg} \mathrm{L}^{-1}\right)$ increases the removal percentage of MB. This could be due to the availability of vacant functional groups on the surface of the adsorbent (Figure 7a). Further increase in contact time leads to the occupation of active sites, which results in saturation of the cell surface of the alga, causing a state of equilibrium and no additional adsorption. In comparison to previous studies, the current study detected the shortest contact time to reach equilibrium between $U$. lactuca and MB (Table 4). 
(a)

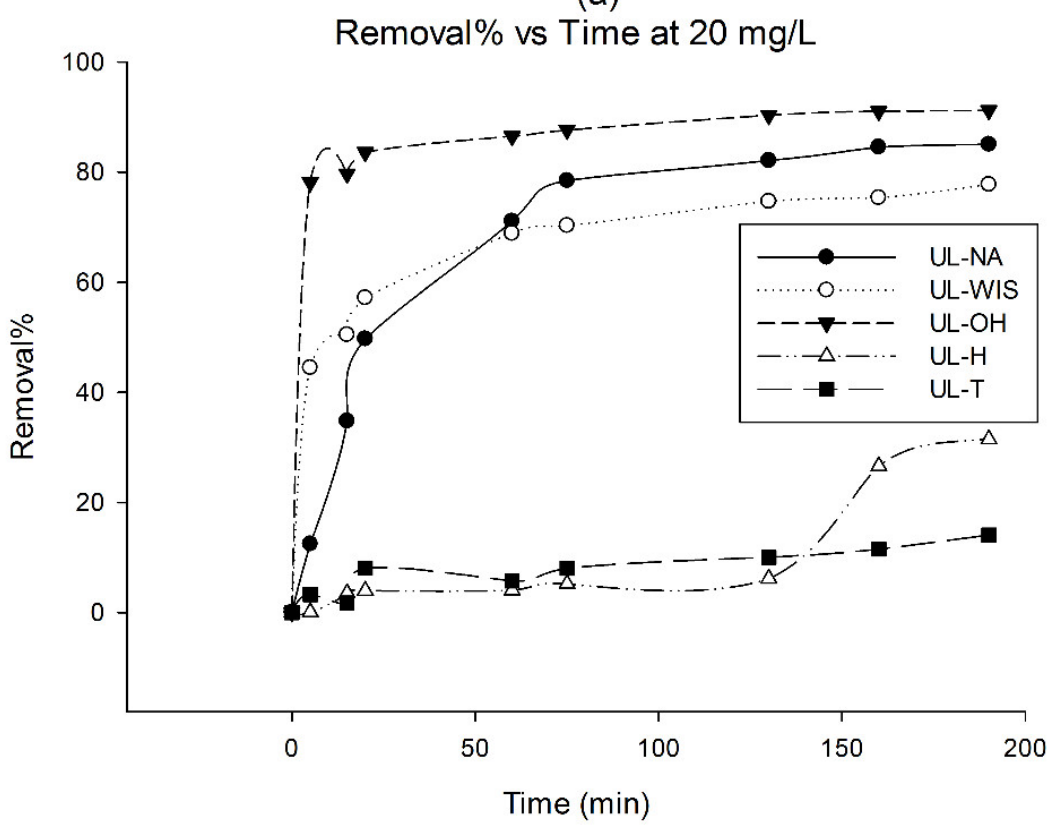

(b)

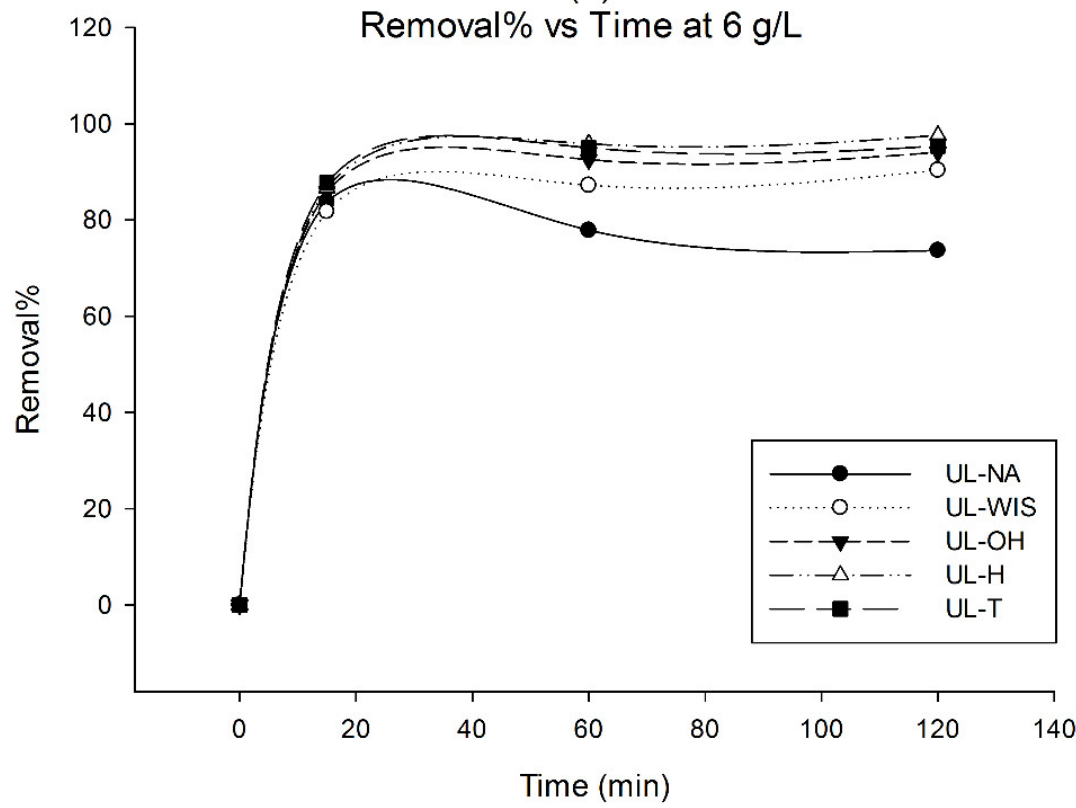

Figure 7. Effect of time on the biosorption of dye with initial concentration of $\mathrm{MB}=5 \times 10^{-5} \mathrm{~mol} / \mathrm{L}$, $\mathrm{pH}=8$; low conc. $20 \mathrm{mg} \cdot \mathrm{L}^{-1}$ (a) and high conc. $6 \mathrm{~g} \cdot \mathrm{L}^{-1}(\mathbf{b})$. 
Table 4. Equilibrium time for biosorption of MB with $U$. lactuca.

\begin{tabular}{|c|c|c|c|c|c|c|c|c|}
\hline \multirow{2}{*}{$\begin{array}{l}\text { Contact } \\
\text { Time } \\
\text { (min) }\end{array}$} & \multirow{2}{*}{$\begin{array}{l}\text { MB mg } \\
\mathrm{L}^{-1}\end{array}$} & \multicolumn{2}{|c|}{ Removal\% } & \multirow{2}{*}{$\begin{array}{c}\begin{array}{c}\text { Capacity } \\
\text { Adsorption } \mathrm{mg} \mathrm{g}^{-1}\end{array} \\
20 \mathrm{mg} \mathrm{L}^{-1}\end{array}$} & \multirow{2}{*}{$\begin{array}{l}\text { Algal Dose } \\
\qquad \mathrm{g} \mathrm{L}^{-1}\end{array}$} & \multirow{2}{*}{$\mathrm{pH}$} & \multirow{2}{*}{ Treatment } & \multirow{2}{*}{ References } \\
\hline & & $\begin{array}{c}20 \mathrm{mg} \\
\mathrm{L}^{-1}\end{array}$ & $6 \mathrm{~g} \mathrm{~L}^{-1}$ & & & & & \\
\hline \multirow{5}{*}{75} & \multirow{5}{*}{16} & 78.44 & 75.00 & 263.2 & \multirow{5}{*}{5} & \multirow{5}{*}{8} & UL-NA & \multirow{5}{*}{$\begin{array}{l}\text { Current } \\
\text { study }\end{array}$} \\
\hline & & 70.28 & 90.34 & 303 & & & UL-WIS & \\
\hline & & 87.61 & 95.35 & 625 & & & UL-OH & \\
\hline & & 5.00 & 95.38 & 2 & & & UL-H & \\
\hline & & 8.04 & 95.37 & 2.9 & & & UL-T & \\
\hline 45 & 25 & \multicolumn{2}{|c|}{75} & 40.2 & 1.25 & 10 & $\begin{array}{c}\mathrm{SW}^{+}+\mathrm{TW}^{\dagger}+\mathrm{ddW}^{\dagger}+ \\
\text { dried }\left(100^{\circ} \mathrm{C}\right)\end{array}$ & [27] \\
\hline 60 & 100 & \multicolumn{2}{|c|}{65.68} & 200 & 2 & 7 & $\begin{array}{c}\mathrm{SW}^{\dagger}+\mathrm{TW}^{\dagger}+\text { dried } \\
\left(\mathrm{RT}^{\dagger}\right)\end{array}$ & {$[63]$} \\
\hline 110 & 25 & \multicolumn{2}{|c|}{91.92} & NA & 1.25 & 8 & $\begin{array}{c}\mathrm{SW}^{\dagger}+\mathrm{TW}^{\dagger}+\mathrm{ddW}^{\dagger}+ \\
\text { dried }\left(100^{\circ} \mathrm{C}\right)\end{array}$ & [28] \\
\hline 180 & 200 & \multicolumn{2}{|c|}{96.59} & 344.83 & 1.5 & 11.16 & $\begin{array}{c}\mathrm{TW}^{\dagger}+\mathrm{dW}^{\dagger}+\text { dried } \\
\left(105^{\circ} \mathrm{C}\right)+\mathrm{ZnCl}_{2}+110 \\
{ }^{\circ} \mathrm{C}+700^{\circ} \mathrm{C}\end{array}$ & [26] \\
\hline
\end{tabular}

${ }^{\dagger} \mathrm{SW}, \mathrm{TW}, \mathrm{dW}, \mathrm{ddW}$, represent the preparation procedure of washing $U$. lactuca biomass to generate bio-adsorbent. SW: sea water; TW: tap water; $\mathrm{dW}$ : distilled water; $\mathrm{ddW}$ : double distilled water; RT: room temperature.

Other factors, such as algal biomass and $\mathrm{pH}$, can influence the adsorption capacity, as mentioned by Karim et al. [64].

\subsection{Effect of Adsorbent Dose}

To examine the effect of the adsorbent of $U$. lactuca in removing the adsorbate (the MB dye), we varied the doses of adsorbent while keeping the MB solution constant $\left(16 \mathrm{mg} \cdot \mathrm{L}^{-1}\right)$. The results obtained have been grouped in the curve in Figure 8. It can clearly be seen that, from $1 \mathrm{~g}$ biomass, the adsorbed quantities of MB no longer evolve for all treatments, except for UL-H and UL-T. This behavior can be illustrated with regard to the increase in the quantity of specific sites for the biosorption of $\mathrm{MB}$ by the variation of the dose of the adsorbents used, and this occurs up to a dose of $5 \mathrm{~g} / \mathrm{L}$. From here the number of sites becomes stable [65,66]. In contrast, Karimel at [67]. have shown that the cationic dye can easily access the biosorption sites as long as the dose of adsorbent used in the dye solution is low. However, the integration of adsorbents makes it possible to increase the number of biosorption sites to form electrostatic bonds, so at a high dose of adsorbent, the solution becomes congested, which makes it difficult for the cationic dye to approach the biosorption sites. Thus, a large dose of adsorbent causes agglomerations of particles in solution and consequently a reduction in the total biosorption surface and a reduction in the amount of adsorbate per unit of mass of adsorbent. The results obtained by Karim et al. [67] and El Sikaily et al. [27] are in agreement with our results for UL-NA, UL-WIS, and UL-OH but are contrary to the results obtained for both UL-H and UL-T [68]. 


\section{Removal\% vs Adsorbent dose at $75 \mathrm{~min}$}

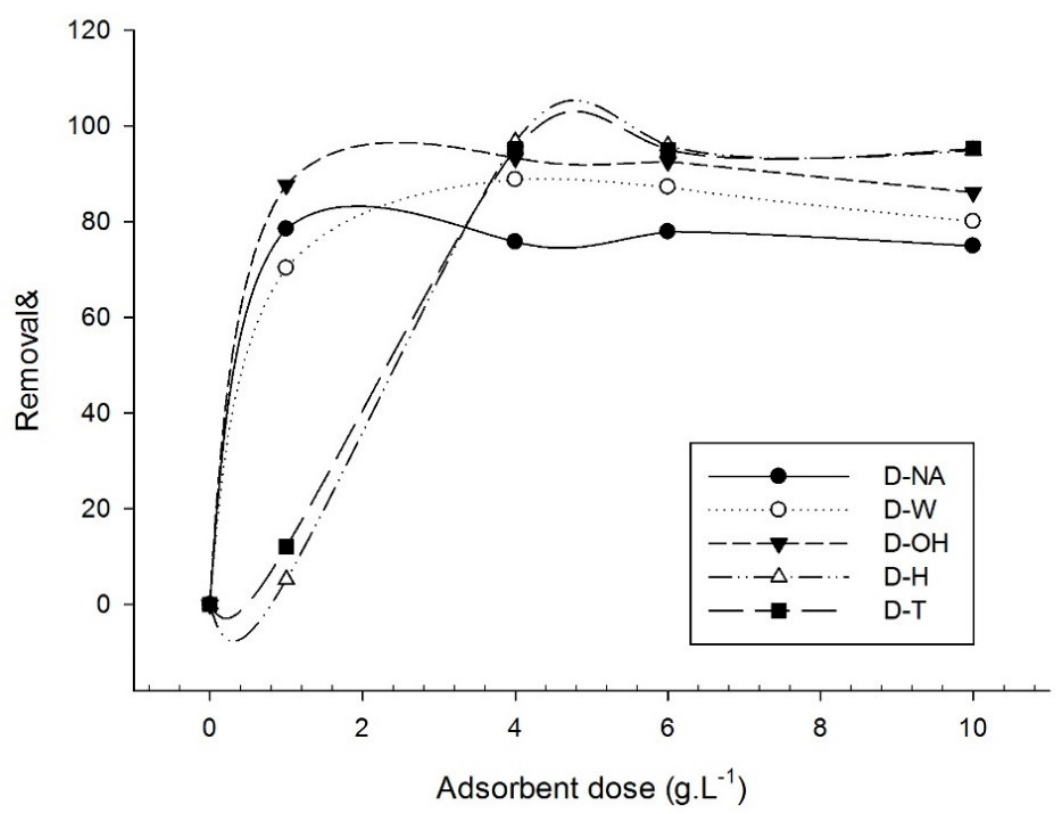

Figure 8. Effect of biomass dose of dry U. lactuca on the removal of MB.

\subsection{Effect of $\mathrm{pH}$ on the Biosorption Process}

The hydrogen ion concentration of the system exerted a profound influence on the complete manner of surface assimilation and in particular on the surface assimilation capacity, influencing the characteristics of the adsorbent, namely the charge of its surface, the degree of ionization in solution, and the detachment of functional groups on the active sites of the adsorbent and together with the dye in solution. In general, at high concentrations of hydrogen ions, the adsorbent favorably adsorbs the anions due to the presence of $\mathrm{H}^{+}$ions; however, at low concentrations of hydrogen ions, the $\mathrm{MB}$ cations are adsorbed due to the negative charges present on surface sites of the adsorbent [69].

Among the characteristics of the MB dye, it presents as a basic and cationic dye, as indicated by the existence in its structure of a positive charge on nitrogen. The effect of $\mathrm{pH}$ can be explained by means of the surface charge on the adsorbent. However, at low $\mathrm{pH}$ values $(\mathrm{pH}<3)$, poor $\mathrm{MB}$ biosorption has been seen due to the increase in the density of positive charge (protons) at surface biomass sites. This is explained by the electrostatic repulsion that occurs between the $\mathrm{MB}$ cations and the positive charges on the surface of the adsorbent [27].

At a higher $\mathrm{pH}$ value $(\mathrm{pH}>3)$, the rate of negative charge increases on the surface of the biomass, which allows for good biosorption of $\mathrm{MB}$ on the surface of the adsorbent. Similar results have been shown for the biosorption of $\mathrm{MB}$ and metals on different adsorbents $[70,71]$. Figure $9 \mathrm{a}-\mathrm{e}$ presents the effect of the variation of $\mathrm{pH}(2,5,8$, and 10$)$ on the elimination of MB from aqueous solution and at different doses of $U$. lactuca $(3,4,5$, and $10 \mathrm{~g} / \mathrm{L})$ and when keeping the $\mathrm{MB}$ concentration constant $\left(16 \mathrm{mg} / \mathrm{L}=5.10^{-5} \mathrm{~mol} / \mathrm{L}\right)$. The results indicate that the initial $\mathrm{pH}$ of the $\mathrm{MB}$ mixture and the different adsorbents, in the order of 7 to 8 , has been found to be favorable for the isolation of $\mathrm{MB}$ by all the treated and untreated biomass of $U$. lactuca. El Jamal and Ncibi [37] found that the favorable $\mathrm{pH}$ for the nonactivated green macroalga Chaetophora elegans was six. At $\mathrm{pH}$ values above eight, the extent of dye removal for all treatments decreases. However, at a very acidic $\mathrm{pH}(\mathrm{pH}=2)$ the percentage of adsorption of $\mathrm{MB}$ on the various adsorbents is low; this is most probably due to the fact that the number of positively charged sites is higher than that of negatively charged sites in medium [72] that favorably adsorbs the anion dyes but not cationic dyes. Thus, at low $\mathrm{pH}$ an increase of positive charge density on biomass surface explains the elec- 
trostatic repulsion between cationic dyes and the positive charged site [27,69]. Furthermore, the biosorption of $\mathrm{MB}$ on the different adsorbents of $U$. lactuca could be due to the strong physical interactions (such as H-bonds) between the adsorbate molecules (MB) and various functional groups, namely hydroxyl, the carbonyl and carboxyl present in the cellulosic cell, and the lignin present in the noncellulosic cell of adsorbents of $U$. lactuca [66].
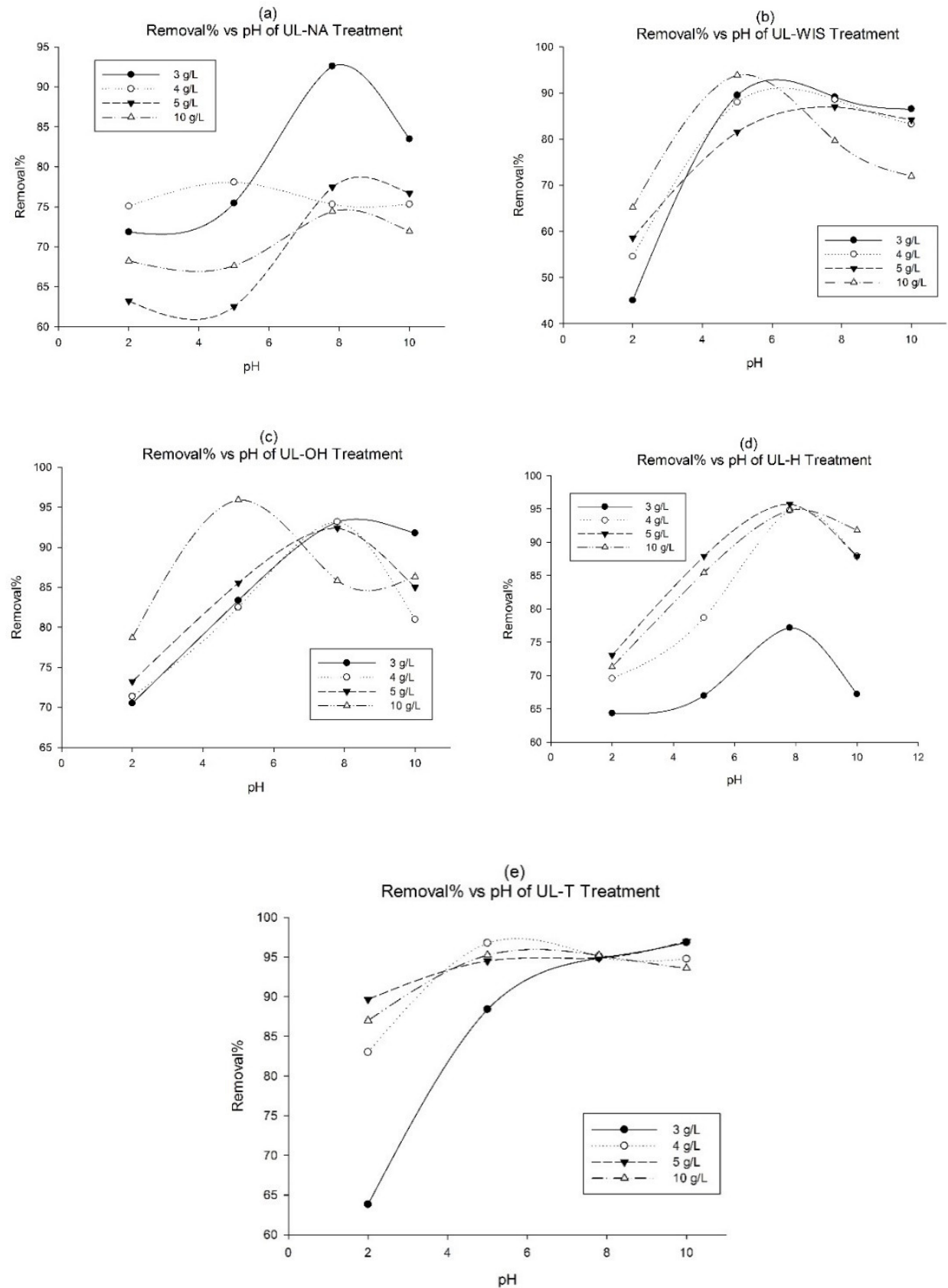

Figure 9. The effect of $\mathrm{pH}$ on adsorption of $\mathrm{MB}$ from aqueous solution onto dry algal biomass, UL-NA (a), UL-WIS (b), $\mathrm{UL-OH}(\mathbf{c}), \mathrm{UL}-\mathrm{H}(\mathbf{d})$ and UL-T (e) at different adsorbent dose.

These results prove that a slightly basic $\mathrm{pH}$, as a condition of natural water bodies, is a good proxy for $\mathrm{MB}$ removal; therefore, there was no need to change the natural value of $\mathrm{pH}$ for the current study's conditions. Note that, for the rest of the experiments, we adopted as a constant for all the mixtures thus prepared a $\mathrm{pH}$ of 8 and dose of adsorbent of $5 \mathrm{~g} \mathrm{~L}^{-1}$. 


\subsection{Biosorption Dynamics Kinetics \\ 3.7.1. Model of the Pseudo-First-Order Kinetics (Lagergren Model)}

The mathematical treatment of Lagergren's speed equation, Equation (6), allows us to solve the expression of first-order speed and to calculate the speed constant of biosorption. However, the pseudo-first-order constants were defined by extrapolating the plot of log (qe - qt) as a function of time (t) (Figure 10a,b). The pseudo-first-order model was applied to the five adsorbents at $20 \mathrm{mg} \mathrm{L}^{-1}$ in order to determine the values of the adsorbed quantities, the pseudo-first-order constant $\mathrm{K} 1$, and the regression coefficient $R^{2}$, which have been grouped in Table 5.

(a)

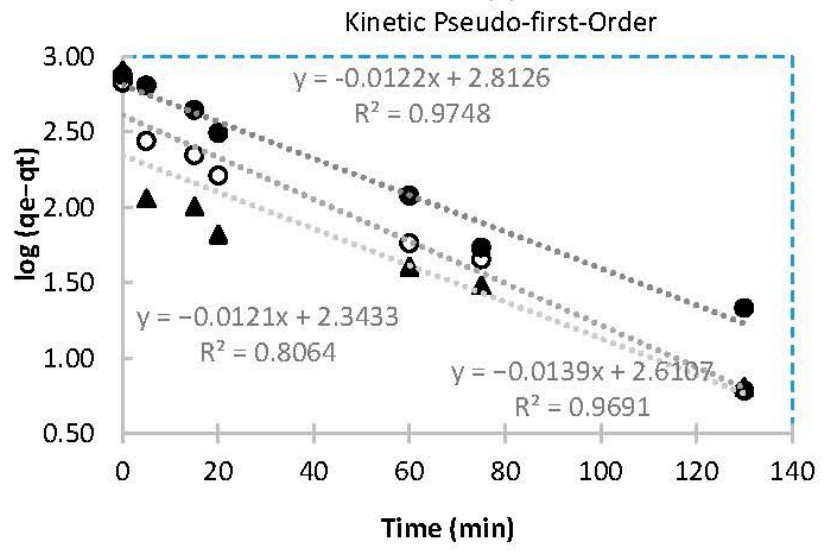

(b)

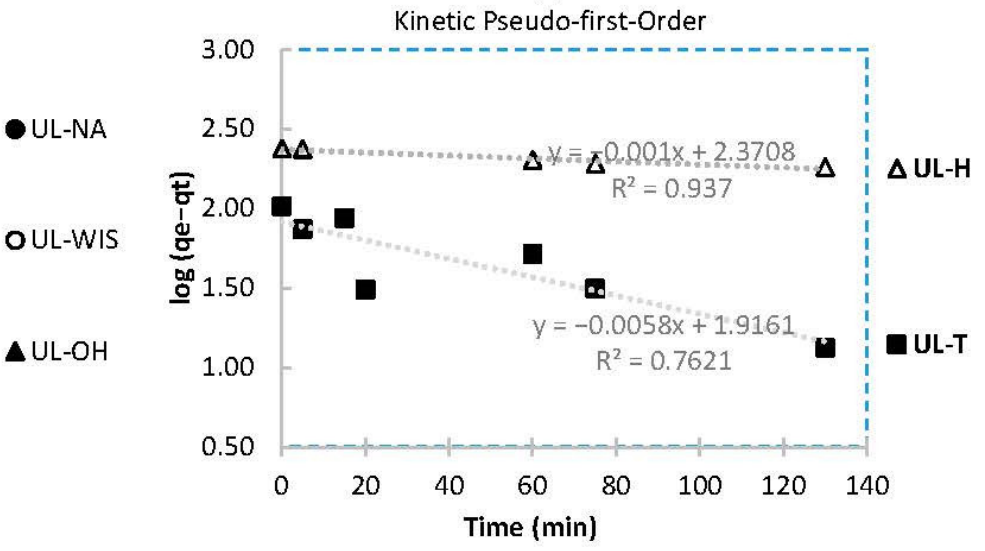

Figure 10. Kinetic pseudo-first-order of MB adsorbed by dry U. lactuca biomass: UL-NA, UL-WIS, and UL-OH (a), UL-H and UL-T (b). Experimental conditions: $5 \mathrm{~g} \mathrm{~L}^{-1}$ of adsorbent concentration, $\mathrm{pH}=8, \mathrm{~T}=25^{\circ} \mathrm{C}, \mathrm{C}_{0}(\mathrm{MB})=5 \times 10^{-5} \mathrm{~mol} / \mathrm{L}$.

Table 5. Kinetic parameters of biosorption of MB on dry U. lactuca biomass.

\begin{tabular}{|c|c|c|c|c|c|c|}
\hline UL-NA. & UL-T & UL-H & UL-OH & UL-WIS & & \\
\hline 0.0276 & 0.0069 & 0.0023 & 0.0276 & 0.0115 & $\mathrm{~K} 1\left(\min ^{-1}\right)$ & \multirow{4}{*}{$\begin{array}{c}\text { Model of } \\
\text { pseudo-first }\end{array}$} \\
\hline 648.63 & 22.59 & 234.42 & 220.29 & 441.57 & $\mathrm{qe}^{*}\left(\mathrm{mg} \cdot \mathrm{g}^{-1}\right)$ & \\
\hline 860.81 & 342.9 & 426.58 & 1990.7 & 2600.73 & $\mathrm{qe}^{*}$ (the.) $*\left(\mathrm{mg} \cdot \mathrm{g}^{-1}\right)$ & \\
\hline 0.974 & 0.762 & 0.937 & 0.806 & 0.969 & $\mathrm{R}^{2}$ & \\
\hline 1000 & 333.3 & 62.5 & 1000 & 1000 & $\mathrm{~K} 2\left(\mathrm{~g} \cdot \mathrm{mg}^{-1} \mathrm{~min}^{-1}\right)$ & \multirow{4}{*}{$\begin{array}{l}\text { Model of } \\
\text { pseudo- } \\
\text { second }\end{array}$} \\
\hline $33.34 \times 10^{-6}$ & $20.55 \times 10^{-6}$ & $755.16 \times 10^{-6}$ & $500.00 \times 10^{-6}$ & $111.11 \times 10^{-6}$ & $\mathrm{qe}^{*}\left(\mathrm{mg} \cdot \mathrm{g}^{-1}\right)$ & \\
\hline $24.46 \times 10^{-6}$ & 27.51 & $942.59 \times 10^{-6}$ & $596.09 \times 10^{-6}$ & $59.06 \times 10^{-6}$ & $\mathrm{qe}^{*}$ (the.) $\left(\mathrm{mg} \cdot \mathrm{g}^{-1}\right)$ & \\
\hline 0.986 & 0.592 & 0.940 & 0.999 & 0.998 & $R^{2}$ & \\
\hline 546.37 & $-847 \times 10^{-6}$ & 16.46 & $431610^{6}$ & 1350 & $\alpha$ & \multirow{3}{*}{$\begin{array}{l}\text { Elovich } \\
\text { model }\end{array}$} \\
\hline 0.0049 & -0.0736 & 0.1069 & 0.0293 & 0.0113 & $\beta$ & \\
\hline 0.979 & 0.094 & 0.867 & 0.951 & 0.978 & $\mathrm{R}^{2}$ & \\
\hline 143.05 & 19.31 & 16.23 & 18.99 & 46.82 & $\begin{array}{c}\text { Kint1 } \\
\left(\mathrm{mg} \cdot \mathrm{g}^{-1} \min ^{1 / 2}\right)\end{array}$ & \multirow{6}{*}{$\begin{array}{c}\text { Intraparticle } \\
\text { diffusion } \\
\text { model }\end{array}$} \\
\hline-215.8 & -33.1 & -34.7 & 651.7 & 287.7 & $\mathrm{C}\left(\mathrm{cm}^{2} \cdot \mathrm{s}^{-1}\right)$ & \\
\hline 0.978 & 0.760 & 0.978 & 0.761 & 0.917 & $\mathrm{R}^{2}$ & \\
\hline 23.46 & 3.52 & 4.73 & 9.20 & 14.18 & $\begin{array}{c}\text { Kint2 } \\
\left(\mathrm{mg} \cdot \mathrm{g}^{-1} \cdot \min ^{1 / 2}\right)\end{array}$ & \\
\hline 472.3 & 51.8 & 1.9 & 702 & 505.3 & $\mathrm{D}^{*}\left(\mathrm{~cm}^{2} \cdot \mathrm{s}^{-1}\right)$ & \\
\hline 0.793 & 0.188 & 0.892 & 0.998 & 0.999 & $\mathrm{R}^{2}$ & \\
\hline
\end{tabular}

${ }^{*}$ qe (the.): the theoretical adsorption capacity at equilibrium $\left(\mathrm{mg} \mathrm{g}^{-1}\right)$. D: diffusivity of solute in adsorbent.

The values of $R^{2}$ were found to be relatively low and between 0.762 and 0.806 for UL-T and UL-OH but higher than 0.9 for UL-H, UL-WIS, and UL-NA. The calculation of qe for the differently treated $U$. lactuca biomass shows that the quantities of $\mathrm{MB}$ adsorbent are high compared to the experimental quantities, except for UL-H and UL-NA, which give a 
close value. These facts lead us to conclude that the biosorption of MB does not reveal a process of controlled diffusion because it does not follow the pseudo-equation of the first wave given by Lagergren, except for the adsorbents UL-H and UL-NA [73].

\subsubsection{Model of the Pseudo-Second-Order Kinetics}

The pseudo-second-order kinetic model (Equation (7)) was applied to the different adsorbents of $U$. lactuca in order to verify the biosorption mode of MB. The results obtained are shown in Figure 11a,b. Table 5 shows the calculated values of adsorbed quantities qe $2 \mathrm{~s}$, pseudo-second-order constant K2, and regression coefficient $R^{2}$. Overall, it appears that the values of $R^{2}$ are high, with all in the order of 0.99 , and far exceed those obtained with the pseudo-first-order model, except for UL-T $\left(R^{2}=0.592\right)$ and UL-H $\left(R^{2}=0.940\right)$. The biosorption capacities at equilibrium (qe2) are comparable to the theoretical values. These last two observations lead us to believe that the UL-WIS, UL-OH, and UL-NA biosorption process follows the pseudo-second-order mode.

(a)

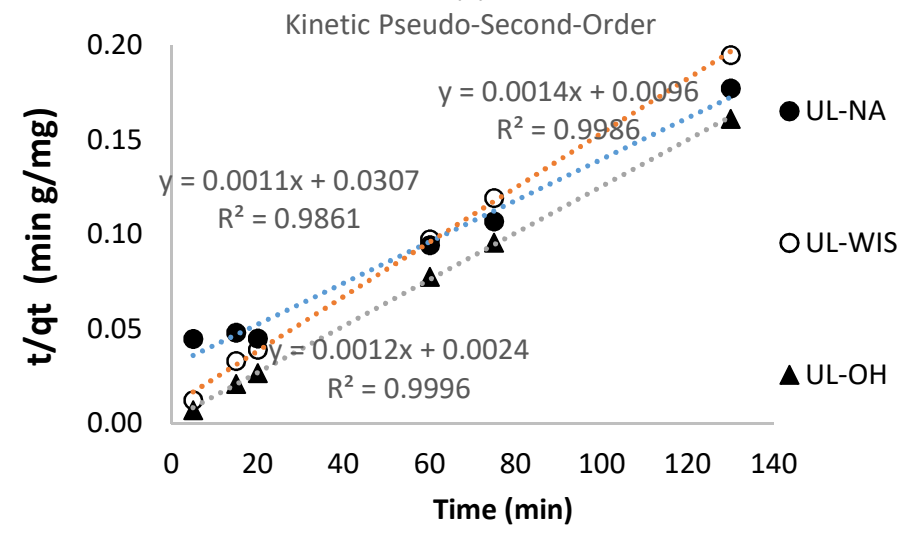

(b)

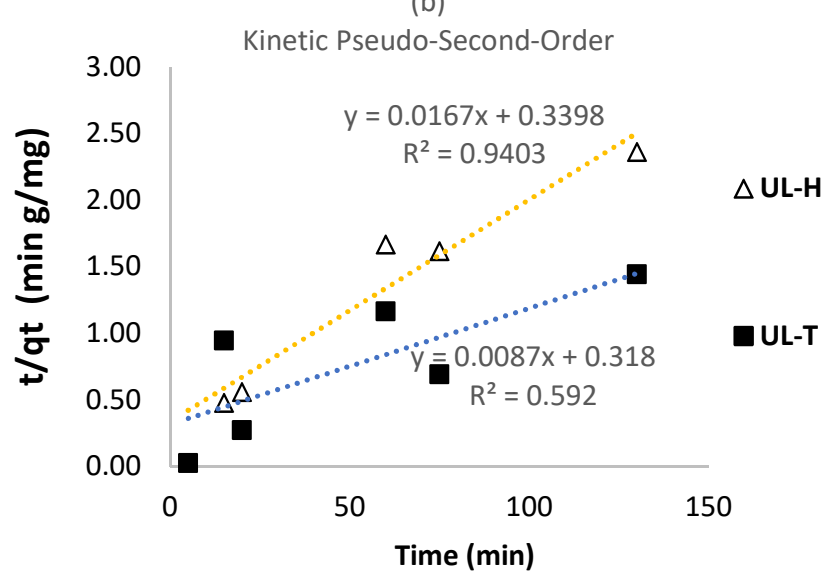

Figure 11. Kinetic pseudo-second-order of MB adsorbed by dry U. lactuca biomass: UL-NA, UL-WIS, and UL-OH (a), UL-H and UL-T (b). Experimental conditions: $5 \mathrm{~g} \mathrm{~L}^{-1}$ adsorbent concentration, $\mathrm{pH}=8, \mathrm{~T}=25^{\circ} \mathrm{C}, \mathrm{C} 0(\mathrm{MB})=5 \times 10^{-5} \mathrm{~mol} / \mathrm{L}$.

\subsubsection{Intraparticle Diffusion Model}

In order to verify the adaptation of the diffusion mechanisms of the different $U$. lactuca adsorbents, the kinetic results were analyzed using the intraparticle diffusion model. According to Weber and Morris [40], the kinetic expression of intraparticle scattering is frequently given by Equation (8). The plot of qt in terms of $t^{0.5}$, illustrated in Figure 12a,b, gives multilinear curves for each treated biomass studied, but it does not pass through the origin. This signals that intraparticle diffusion is engaged in the biosorption process, but it is not the only mechanism applied. In addition, the y-intercept of the curves tells us the thickness of the boundary layer. However, the higher the value of the intercept, the greater the effect of the boundary layer $[74,75]$. 
(a)

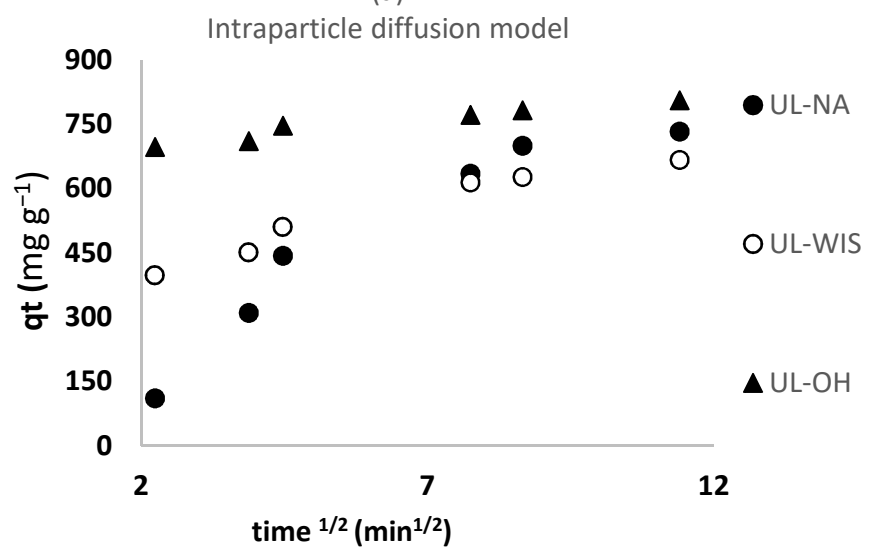

(b)

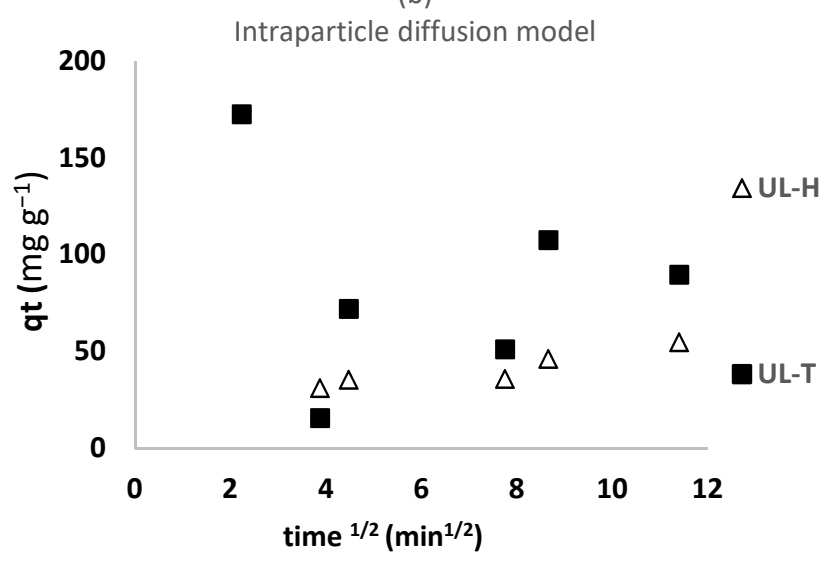

Figure 12. Intraparticle diffusion model of MB adsorbed by dry U. Lactuca biomass: UL-NA, UL-WIS, and UL-OH (a), UL-H and UL-T (b). Experimental conditions: $5 \mathrm{~g} \mathrm{~L}^{-1}$ adsorbent concentration, $\mathrm{pH}=8, \mathrm{~T}=25^{\circ} \mathrm{C}, \mathrm{C}_{0}(\mathrm{MB})=5 \times 10^{-5} \mathrm{~mol} \mathrm{~L}^{-1}$.

The first linearity represents the instantaneous biosorption (called the biosorption phase) on the aerial surface, while the second level describes the phase of progressive biosorption - called intraparticle diffusion - that indicates the limiting phase of the biosorption mechanism. Table 5 shows the intraparticle diffusion constants (Ki1, Ki2), which are calculated using Equation (8). As expected, the diffusion rate constant (Ki1) in the first phase is more remarkable than in the second phase (Ki2), which proves that MB was first adsorbed by the external surface due to the high rate of biosorption. After the complete saturation of the external surface, the dye molecules diffuse in the internal cavities of the adsorbent to be finally adsorbed in the internal surface. However, once the MB molecules diffuse through the adsorbent, whether in the internal cavities or along the external wall, the diffusion resistance of the dye increases, and consequently there is a reduction in the diffusion rate. This results in a decrease in the diffusion rate. This phenomenon is favored for the water insoluble substance (UL-WIS $\left.\left(R^{2}=0.999\right)\right)$ and Ulva treated with sodium hydroxide (UL-OH $\left(R^{2}=0.998\right)$ ).

\subsection{Elovich's Model}

Elovich's model uses a kinetic equation associated with the chemisorption process [76]. This equation (Equation (9)) is frequently used for an adsorbent system containing a heterogeneous surface (Figure 13).

Table 5 indicates that the $R^{2}$ values found by the pseudo-second-order model are more important than those found by the pseudo-first-order, intraparticle diffusion, and Elovich models. These results prove that UL-WIS, UL-OH, UL-H, and UL-NA describe the kinetic model of the pseudo-second-order more precisely, whereas UL-T describes a kinetic model of the pseudo-first order with $\mathrm{MB}$ as the adsorbate. Likewise, the calculated $\left(\mathrm{q}_{\mathrm{e}, \text { calc }}\right)$ and experimental $\left(\mathrm{q}_{\mathrm{e}, \text { exp }}\right)$ values obtained from the pseudo-second-order model were more consistent than those found from the pseudo-first-order model.

Note that the pseudo-second-order model has been described as being the best biosorption model for cationic dyes, in preference to other adsorbents, as was investigated by Chowdhury and Saha [77], and Maurya et al. [78] who found biosorption of MB on hen feathers and the green microalga Microspora sp. 


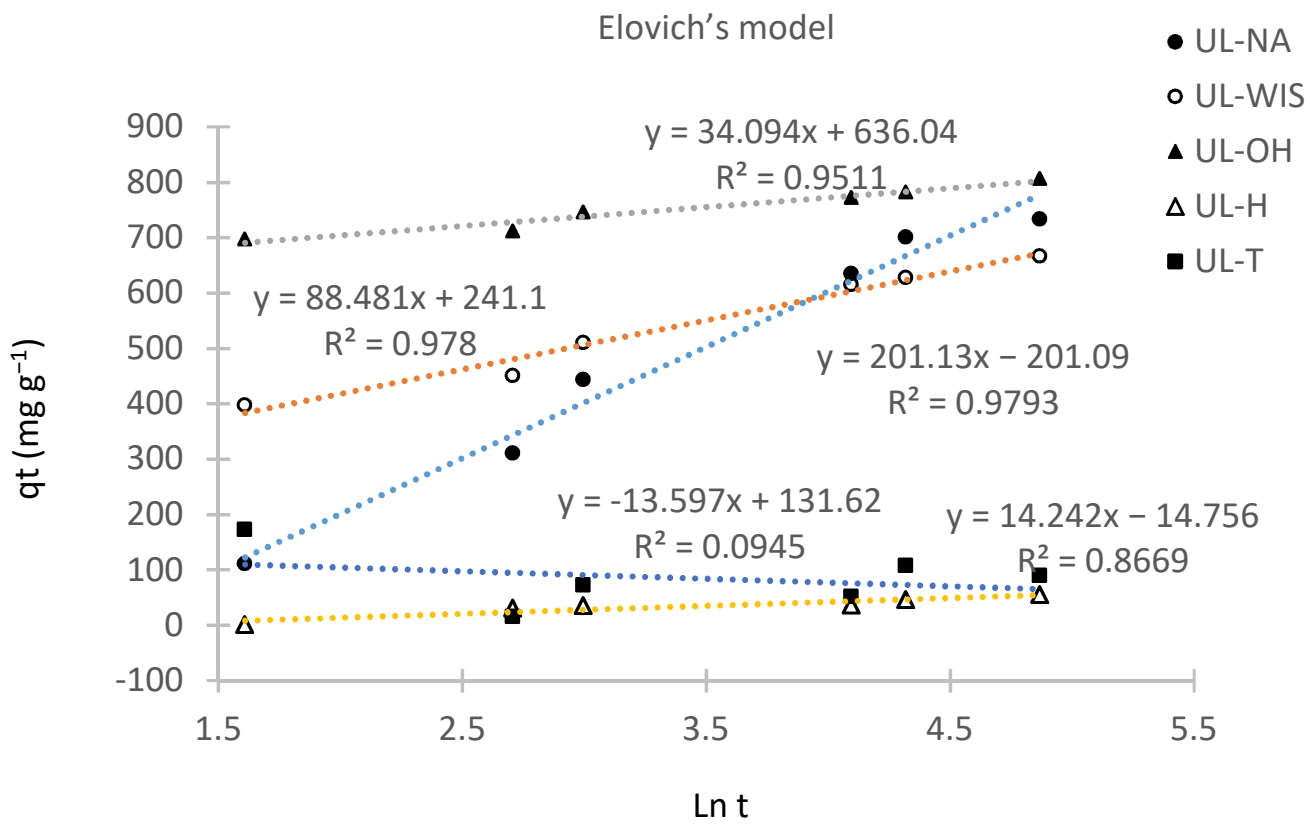

Figure 13. Elovich's model of $\mathrm{MB}$ adsorbed by dry U. Lactuca biomass. Experimental conditions: $5 \mathrm{~g} \mathrm{~L}^{-1}$ adsorbent concentration, $\mathrm{pH}=8, \mathrm{~T}=25^{\circ} \mathrm{C}, \mathrm{C}_{0}(\mathrm{MB})=16 \mathrm{mg} \mathrm{L}^{-1}$.

\subsection{Adsorption Isotherm}

In the case of treated and untreated $U$. lactuca, Langmuir and Freundlich constants (Table 6) were determined from the linearized form given by Equations (10) and (12) (Figures 14 and 15). The regression coefficients obtained by using the Langmuir model are higher for UL-OH $\left(R^{2}=0.9985\right)$, UL-WIS $\left(R^{2}=0.9836\right)$, and UL-NA $\left(R^{2}=0.9789\right)$. The applicability of the Langmuir model for the MB-biomass algae system (UL-OH, ULWIS, and UL-NA) means that the surface biosorption of MB at the adsorbent level is homogeneous. The values of $\mathrm{q}_{\max }$ obtained for these adsorbents are successively in the order of 625.0, 303.0, and $263.2 \mathrm{mg} \mathrm{g}^{-1}$, which suggests that the Red Sea U. lactuca biomass has a very high capacity for biosorption compared to other types of plant material (Table 7). Thus, for UL-H and UL-T, we noted a lower maximum adsorption capacity, the opposite of MB (2.0 and $2.9 \mathrm{mg} \mathrm{g}^{-1}$, respectively). Therefore, the biosorption processes of MB can be adapted to the treatment of water containing MB in a diluted medium.

Table 6. Langmuir and Freundlich constants for MB.

\begin{tabular}{ccccccccc}
\hline \multicolumn{3}{c}{ Freundlich Constants } & \multicolumn{5}{c}{ Langmuir Constants } \\
\cline { 1 - 6 } $\mathbf{R}^{\mathbf{2}}$ & $\mathbf{K f}$ & $\mathbf{n}$ & $\mathbf{1 / n}$ & $\mathbf{R}^{\mathbf{2}}$ & $\mathbf{R L}$ & $\begin{array}{c}\mathbf{K}_{\mathbf{L}} \\
\mathbf{( L / m g )}\end{array}$ & $\begin{array}{c}\mathbf{q m a x} \\
\mathbf{( m g / g )}\end{array}$ & \\
\hline 0.9762 & 1847 & 1.54 & 0.65 & 0.9836 & 0.12 & 0.363 & 303.0 & UL-WIS \\
0.9819 & 899 & 5.55 & 0.18 & 0.9985 & 0.40 & 0.083 & 625.0 & UL-OH \\
0.9943 & ID & 0.05 & 20.04 & 0.9575 & 0.47 & 0.062 & 2.0 & UL-H \\
0.9478 & ID & 0.05 & 19.22 & 0.9096 & 0.47 & 0.064 & 2.9 & UL-T \\
0.9403 & 1665 & 1.56 & 0.64 & 0.9789 & 0.13 & 0.369 & 263.0 & UL-NA \\
\hline
\end{tabular}




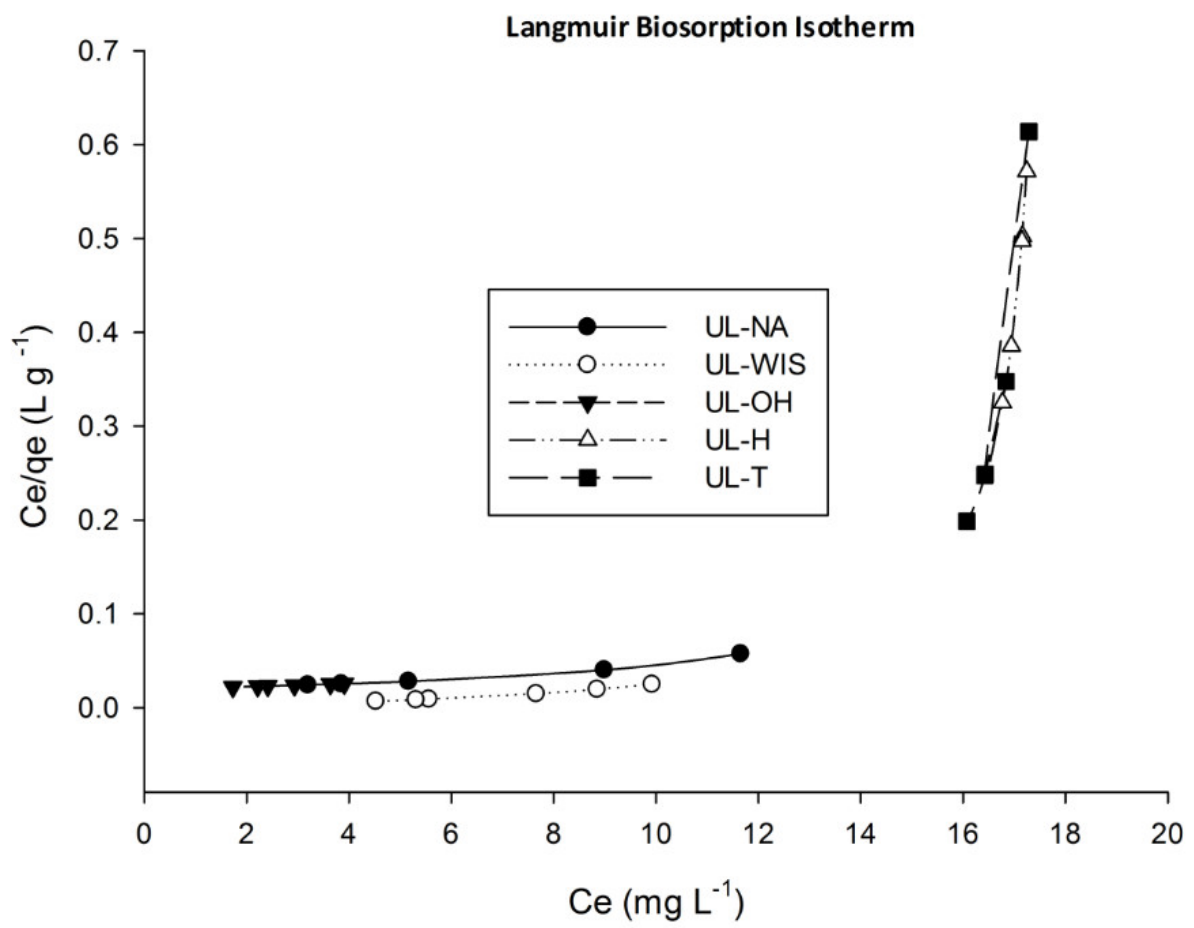

Figure 14. Langmuir biosorption isotherm for the five adsorbents for $\mathrm{MB}$. Temperature $=25^{\circ} \mathrm{C} \pm 1$, $\mathrm{rpm}=200 \pm 1$, adsorbent concentration $=5 \mathrm{~g} \mathrm{~L}^{-1}$, equilibrium time $=75 \mathrm{~min}, \mathrm{pH}=8$.

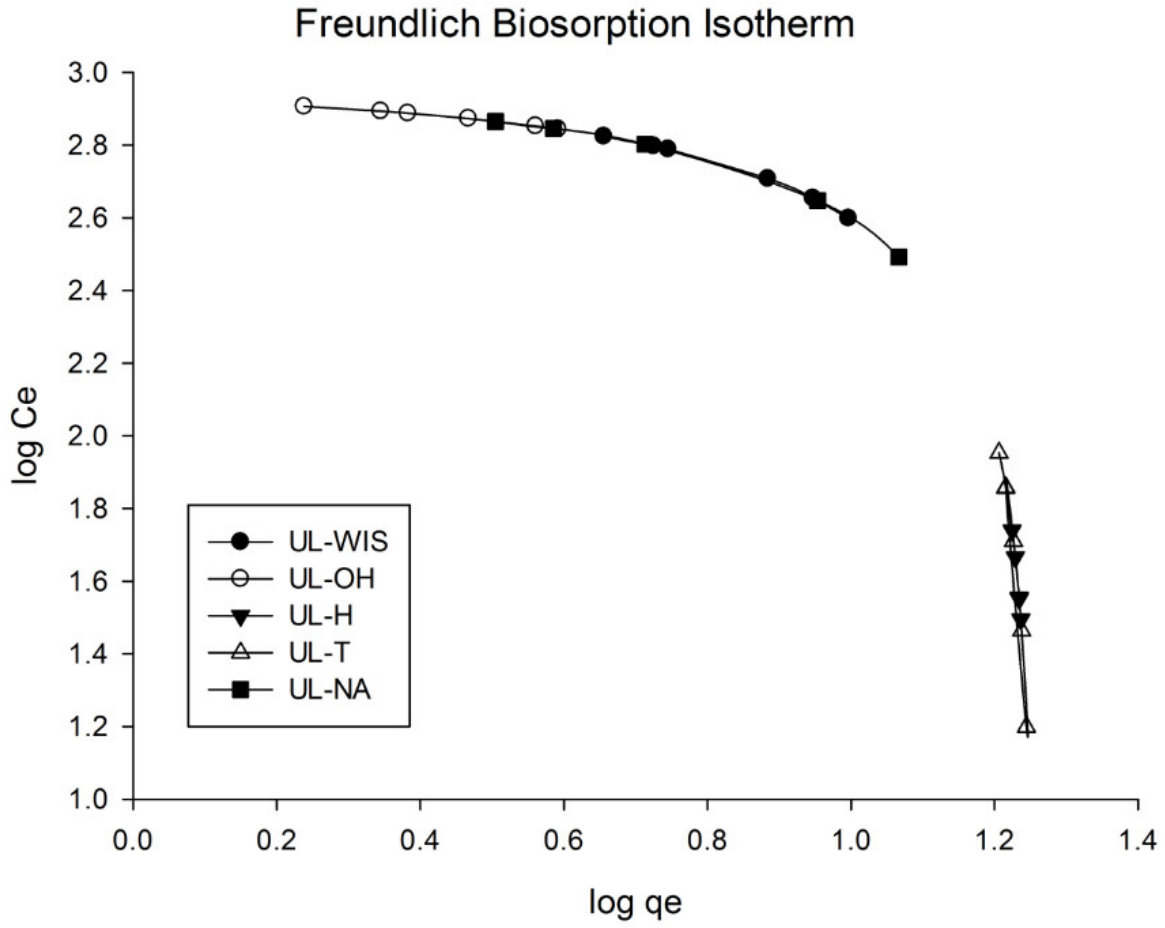

Figure 15. Freundlich biosorption isotherm for the five adsorbents for $\mathrm{MB}$. Temperature $=25^{\circ} \mathrm{C} \pm 1$, $\mathrm{rpm}=200 \pm 1$, adsorbent concentration $=5 \mathrm{~g} \mathrm{~L}^{-1}$, equilibrium time $=75 \mathrm{~min}, \mathrm{pH}=8$.

The biosorption intensity between the adsorbate and the adsorbent in the Freundlich model is deduced by the coefficient $1 / \mathrm{n}$, which is a value between 0 and 1 in the present study; $1 / \mathrm{n}$ values in Table 6 for the dried macroalga U. lactuca ranged from 0.18 to 0.65 for UL-WIS, UL-OH, and UL-NA, which indicates the favorable biosorption of the adsorbate 
(MB). Active dried algae in the presence of acid and carbon (UL-H and UL-T) show a high value of $1 / \mathrm{n}$, ranging from 20.04 to 19.22, respectively, signaling a cooperative biosorption; this implies a strong interaction between MB molecules [79].

However, the Freundlich model admits that the isolation of the adsorbate is carried out by means of a heterogeneous adsorbent surface and can be adapted to multilayer adsorption. This is generally used to explain the adsorption properties of the heterogeneous surface [80], while the Langmuir model explains and helps with the maximum adsorption capacity, which is of the monolayer type. Thus, the monolayer adsorption occurs at particular homogenous sites on the adsorbent [81].

In this study, it can be observed in Table 6 that the base-activated carbon UL-OH prepared from $U$. lactuca biomass can be used as an efficient adsorbent for the adsorption of $\mathrm{MB}$ in aqueous solution. This result is in agreement with the result of activated carbon obtained from Ficus carica [82] and commercial activated carbon (Merk) [54]. Thus, further studies must be conducted to test the effect of low concentrations of $\mathrm{NaOH}$ on the adsorption capacity of activated carbon developed from $U$. lactuca.

All macro- and micro-algae can be used as bio-adsorbents; however, based on local observations, $U$. lactuca is the most available alga along the Red Sea coast due to its ability to bear the severe environmental conditions as well as the ease of its collection in large amounts from the coast without effort or manpower. In addition, the obtained results in the present study support the above-mentioned advantages of using $U$. lactuca as bio-adsorbent compared to (1) other adsorbents, (2) other biomass, or even (3) U. lactuca collected from other locations, as shown in Tables 4 and 7.

Table 7. Adsorption capacities of adsorbents for the removal of MB based on the review of Rafatullah et al. [83].

\begin{tabular}{|c|c|c|}
\hline Adsorbents & Adsorption Capacity (mg.g $\left.{ }^{-1}\right)$ & References \\
\hline Ulva lactuca (UL-OH) & 625.0 & Present study \\
\hline Poly(methacrylic acid) modified biomass of baker's yeast & 869.6 & [84] \\
\hline Poly(amic acid) modified biomass of baker's yeast & 680.3 & [85] \\
\hline Caulerpa lentillifera & 417.0 & [86] \\
\hline Alga Sargassum muticum seaweed & 279.2 & [9] \\
\hline Enteromorpha spp. & 274.0 & [87] \\
\hline Activated sludge biomass & 256.4 & [88] \\
\hline Dead macrofungi (Fomes fomentarius) & 232.7 & [89] \\
\hline Dead macrofungi (Phellinus igniarius) & 204.4 & [89] \\
\hline Hydrilla verticillata & 198.0 & [90] \\
\hline Moss & 185.0 & [5] \\
\hline Algae Gelidium & 171.0 & [91] \\
\hline Duckweed (Spirodela polyrrhiza) (at pH 9) & 144.9 & [92] \\
\hline Water hyacinth root & 128.9 & [5] \\
\hline Duckweed (Spirodela polyrrhiza) (at pH 7) & 119.0 & [92] \\
\hline Algal waste & 104.0 & [91] \\
\hline Composite material & 74.0 & {$[91]$} \\
\hline Unmodified biomass of baker's yeast & 51.5 & {$[84,85]$} \\
\hline Green alga Ulva lactuca & 40.2 & {$[27]$} \\
\hline Brown alga Cystoseira barbatula Kutzing & 38.6 & [93] \\
\hline Dead Streptomyces rimosus & 34.3 & [94] \\
\hline Dead fungus Aspergillus niger & 18.5 & [95] \\
\hline Posidonia oceanica (L.) fibres & 5.6 & {$[87]$} \\
\hline Caulerpa racemosa var. cylindracea & 5.2 & [96] \\
\hline Living biomass & 1.2 & [95] \\
\hline
\end{tabular}

The novelty of this study can be summarized in the activation of dried U. lactuca collected from the Red Sea by different chemical and pyrolysis treatments. Most of previous studies utilized U. lactuca without activation [26-29]. The current study shows the highest adsorption capacity (625 mg/g of UL-OH) in comparison to previous studies conducted by El Nemr et al., [26], El Sikaily et al., [27] who found the adsorption capacity of U. lactuca to 
be $344.83 \mathrm{mg} \mathrm{g}^{-1}$ and $42 \mathrm{mg} \mathrm{g}^{-1}$, respectively. Other researchers, such as Pratiwi et al., [28], have demonstrated that $1.25 \mathrm{mg} \mathrm{g}^{-1}$ removes $91.92 \%$ at a long contact time of $110 \mathrm{~min}$ of $25 \mathrm{mg} \mathrm{L}^{-1} \mathrm{MB}$ in comparison to the current study and that nonactivated $U$. lactuca removed $78.44 \%$ at a concentration of $20 \mathrm{mg} \cdot \mathrm{L}^{-1}$ and $75 \%$ at a concentration of $6 \mathrm{~g} \cdot \mathrm{L}^{-1}$ for a shorter time interval (75 min). Moreover, Vakili et al. [97] mentioned that surfaces with higher adsorption capacity require a longer time for equilibrium, indicating that larger capacity is counterbalanced by a longer treatment time and vice versa. The present study contradicts this hypothesis, as the best adsorption capacity was reached by UL-OH $\left(625 \mathrm{mg} \mathrm{g}^{-1}\right)$ at only $75 \mathrm{~min}$. Based on these results, new hypotheses might be generated, as the treatment process of adsorbent is the main factor managing the adsorption capacity.

\section{Conclusions}

In this study, activated carbon was obtained from dry U. lactuca (UL-NA) by chemical treated with different reagents and by carbonization to obtain UL-H, UL-OH, and UL-T. Furthermore, the solubilization of dry U. lactuca (UL-NA) in double-ionized water gave a water insoluble substance (UL-WIS). However, treated or untreated biomass was adopted as a high-performance adsorbent for the isolation of $\mathrm{MB}$ in aqueous solutions. The success of this research can be explained by the rapid retention of MB molecules on biomass, with an optimal contact time of $75 \mathrm{~min}$, thus revealing the character of an effective adsorbent specific to basic dyes and more specifically of $\mathrm{MB}$ in aqueous solution. In addition, the optimal values of $\mathrm{pH}$ and of the doses of treated and untreated biomass of $U$. lactuca in an aqueous solution of MB were 8 and $5 \mathrm{~g} \mathrm{~L}^{-1}$, respectively. The kinetic model of the pseudo-second-order also justified better retention of $\mathrm{MB}$ on most of the treated and untreated biomasses, with the exception of UL-T, which describes a kinetic model of the pseudo-first order, with MB as the adsorbate. The Langmuir and Freundlich mathematical models explained that the biosorption parameters of $\mathrm{MB}$ on treated and untreated $U$. lactuca biomass are favorable for UL-OH, UL-WIS, and UL-NA as well as UL-H and ULT, respectively, thus indicating that the best adsorption capacity $\left(625.0 \mathrm{mg} \mathrm{g}^{-1}\right)$ was found for the biomass treated in solution with $\mathrm{NaOH}(\mathrm{UL}-\mathrm{OH})$. This suggests a monolayer adsorption on an energetically homogenous surface compared to previous studies. The FTIR, EDX, and SEM studies indicate the presence of oxygenated functional groups with a high porous specific surface. However, there is a direct relationship between the rate of biosorption of $\mathrm{MB}$ and the quantity of the adsorbent (treated or untreated), which can be explained by the large number of unoccupied reactive cavities of $U$. lactuca. It is concluded from this study that the activated carbon with basic medium (UL-OH) as well as the water insoluble substance (UL-WIS) obtained from the dry U. lactuca are promising and effective adsorbents for reducing MB from aqueous solution. Thus, these can be used in the future as low-cost and promising substitutes for the biosorption of MB from industrial waters. However, further investigations must be conducted to test the efficiency of activated biomass of $U$. lactuca as adsorbent of other cationic, anionic heavy metals and industrial pollutants. The present study suggests combining two or more activation processes in $U$. lactuca biomass to investigate any improvement of $U$. lactuca biosorption. Based on the best adsorption capacity obtained in this study, different concentrations of alkali solution $(\mathrm{NaOH})$ should be tested to explore the effect of low concentration on the activation efficiency of biomass.

Supplementary Materials: The following are available online at https:/ / www.mdpi.com/article/ 10.3390/w13091154/s1, Figure S1: MB standard curve at pH8, Figure S2: TEM micrograph of raw dry U. lactuca (UL-NA), UL-WIS, and differently treated U. lactuca (UL-OH, UL-H, UL-T) before (a) and after $75 \mathrm{~min}$ of contact with methylene blue (b) at 1500 magnification. Table S1: Loss of mass of different biomass compared to the non-activated algae (UL-NA).

Author Contributions: Both authors contributed equally in this study, including experiment performance, data analyses, discussion, writing, and reviewing. All authors have read and agreed to the published version of the manuscript. 
Funding: This research received supporting by Taif University Researchers Supporting Project, number (TURSP-2020/242), Taif University, Taif, Saudi Arabia.

Institutional Review Board Statement: Not applicable.

Informed Consent Statement: Not applicable.

Data Availability Statement: Data presented in this study are available on request from the corresponding author.

Acknowledgments: The authors gratefully acknowledge Taif University Researchers Supporting Project, number (TURSP-2020/242), Taif University, Taif, Saudi Arabia.

Conflicts of Interest: The authors declare no conflict of interest.

\section{References}

1. Kannan, N.; Sundaram, M.M. Kinetics and mechanism of removal of methylene blue by adsorption on various carbons-A comparative study. Dye. Pigment. 2001, 51, 25-40. [CrossRef]

2. Sarma, G.K.; SenGupta, S.; Bhattacharyya, K.G. Methylene Blue Adsorption on Natural and Modified Clays. Sep. Sci. Technol. 2011, 46, 1602-1614. [CrossRef]

3. Hao, O.J.K.; Kim, H.; Chaing, P.C. Decolorization of wastewater. Critical Reviews. Environ. Sci. Technol. 2000, 30, 449-505. [CrossRef]

4. Gong, R.; Ding, Y.; Li, M.; Yang, C.; Liu, H.; Sun, Y. Utilization of powdered peanut hull as biosorbent for removal of anionic dyes from aqueous solution. Dye. Pigment. 2005, 64, 187-192. [CrossRef]

5. Low, K.S.; Lee, C.K.; Tan, K.K. Biosorption of basic dyes by water hyacinth roots. Bioresour. Technol. 1995, 52, 79-83. [CrossRef]

6. Lee, C.K.; Low, K.S.; Chung, L.C. Removal of Some Organic Dyes by Hexane-Extracted Spent Bleaching Earth. J. Chem. Technol. Biotechnol. 1997, 69, 93-99. [CrossRef]

7. Banat, F.; Al-Asheh, S.; Al-Makhadmeh, L. Evaluation of the use of raw and activated date pits as potential adsorbents for dye containing waters. Process. Biochem. 2003, 39, 193-202. [CrossRef]

8. Ab Rahman, I.; Saad, B. Utilization of Guava Seeds as a Source of Activated Carbon for Removal of Methylene Blue from Aqueous Solution. Malays. J. Chem. 2003, 5, 008-014.

9. Rubin, E.; Rodriguez, P.; Herrero, R.; Cremades, J.; Barbara, I.; Vicente, M.E.S.D. Removal of Methylene Blue from aqueous solutions using as biosorbentSargassum muticum: An invasive macroalga in Europe. J. Chem. Technol. Biotechnol. 2005, 80, 291-298. [CrossRef]

10. Rajeshwarisivaraj; Subburam, V. Activated parthenium carbon as an adsorbent for the removal of dyes and heavy metal ions from aqueous solution. Bioresour. Technol. 2002, 85, 205-206. [CrossRef]

11. Fu, Y.; Viraraghavan, T. Fungal decolorization of dye wastewaters: A review. Bioresour. Technol. 2001, 79, 251-262. [CrossRef]

12. Rashid, N.; Rehman, M.S.U.; Han, J.-I. Recycling and reuse of spent microalgal biomass for sustainable biofuels. Biochem. Eng. J. 2013, 75, 101-107. [CrossRef]

13. Ponnusamy, S.K.; Pavithra, J.; Suriya, S.; Ramesh, M.; Kumar, K. Sargassum wightii, a marine alga is the source for the production of algal oil, bio-oil, and application in the dye wastewater treatment. Desalin. Water Treat. 2014, 55, 1-17.

14. Abbas, M.N.; Al-Hermizy, S.M.M.; Abudi, Z.N.; Ibrahim, T.A. Phenol Biosorption from Polluted Aqueous Solutions by Ulva Lactuca Alga Using Batch Mode Unit. J. Ecol. Eng. 2019, 20, 225-235. [CrossRef]

15. Alsufyani, T.; Engelen, A.H.; Diekmann, O.E.; Kuegler, S.; Wichard, T. Prevalence and mechanism of polyunsaturated aldehydes production in the green tide forming macroalgal genus Ulva (Ulvales, Chlorophyta). Chem. Phys. Lipids 2014, 183, 100-109. [CrossRef] [PubMed]

16. Ibrahim, W.M.; Hassan, A.F.; Azab, Y.A. Biosorption of toxic heavy metals from aqueous solution by Ulva lactuca activated carbon. Egypt. J. Basic Appl. Sci. 2016, 3, 241-249. [CrossRef]

17. Wong, M.H.; Kwok, T.T.; Ho, K.C. Heavy metals inUlva lactuca collected within Tolo Harbour, an almost landlocked sea. Aquat. Ecol. 1982, 16, 223-230. [CrossRef]

18. Mourad, F.A.; El-Azim, H.A. Use of green alga Ulva lactuca (L.) as an indicator to heavy metal pollution at intertidal waters in Suez Gulf, Aqaba Gulf and Suez Canal, Egypt. Egypt. J. Aquat. Biol. Fish. 2019, 23, 437-449. [CrossRef]

19. Salima, A.; Benaouda, B.; Noureddine, B.; Duclaux, L. Application of Ulva lactuca and Systoceira stricta algae-based activated carbons to hazardous cationic dyes removal from industrial effluents. Water Res. 2013, 47, 3375-3388. [CrossRef] [PubMed]

20. Wong, Y.; Szeto, Y.; Cheung, W.; McKay, G. Adsorption of acid dyes on chitosan-Equilibrium isotherm analyses. Process. Biochem. 2004, 39, 695-704. [CrossRef]

21. Tan, I.; Ahmad, A.; Hameed, B. Adsorption of basic dye on high-surface-area activated carbon prepared from coconut husk: Equilibrium, kinetic and thermodynamic studies. J. Hazard. Mater. 2008, 154, 337-346. [CrossRef] [PubMed]

22. Nazem, M.A.; Zare, M.H.; Shirazian, S. Preparation and optimization of activated nano-carbon production using physical activation by water steam from agricultural wastes. RSC Adv. 2020, 10, 1463-1475. [CrossRef]

23. Trabucco, A.; Marquez, F. Structure of the Glomerular Tuft. J. Urol. 1952, 67, 235-255. [CrossRef] 
24. Nahil, M.A.; Williams, P.T. Pore characteristics of activated carbons from the phosphoric acid chemical activation of cotton stalks. Biomass- Bioenergy 2012, 37, 142-149. [CrossRef]

25. van Oss, C.J. A review of: “Active Carbon.” R.C. Bansal, J.B. Donnet and F. Stoeckli; Marcel Dekker, New York, 1988. pp. 482, \$135. J. Dispers. Sci. Technol. 1990, 11, 323. [CrossRef]

26. El Nemr, A.; Shoaib, A.G.M.; El Sikaily, A.; Mohamed, A.E.-D.A.; Hassan, A.F. Evaluation of Cationic Methylene Blue Dye Removal by High Surface Area Mesoporous Activated Carbon Derived from Ulva lactuca. Environ. Process. 2021, 8, $311-332$. [CrossRef]

27. El Sikaily, A.; Khaled, A.; El Nemr, A.; Abdelwahab, O. Removal of Methylene Blue from aqueous solution by marine green algaUlva lactuca. Chem. Ecol. 2006, 22, 149-157. [CrossRef]

28. Pratiwi, D.; Prasetyo, D.J.; Poeloengasih, C.D. Adsorption of Methylene Blue dye using Marine algae Ulva lactuca. IOP Conf. Ser. Earth Environ. Sci. 2019, 251, 012012. [CrossRef]

29. Zeb, J.; Sultan, M.; Tahir, H. Removal of basic dye methylene blue by using bioabsorbents Ulva lactuca and Sargassum. Afr. J. Biotechnol. 2008, 7, 2649-2655.

30. Makeswari, M.; Santhi, T.; Ezhilarasi, M.R. Adsorption of methylene blue dye by citric acid modified leaves of Ricinus communis from aqueous solutions. J. Chem. Pharm. Res. 2016, 8, 452-462.

31. Cazetta, A.L.; Vargas, A.M.M.; Nogami, E.M.; Kunita, M.H.; Guilherme, M.R.; Martins, A.C.; Silva, T.L.; Moraes, J.C.G.; Almeida, V.C. NaOH-activated carbon of high surface area produced from coconut shell: Kinetics and equilibrium studies from the methylene blue adsorption. Chem. Eng. J. 2011, 174, 117-125. [CrossRef]

32. Sultan, H.; Ahmed, N.; Mubashir, M.; Danish, S. Chemical production of acidified activated carbon and its influences on soil fertility comparative to thermo-pyrolyzed biochar. Sci. Rep. 2020, 10, 1-8. [CrossRef]

33. Tseng, R.-L. Mesopore control of high surface area NaOH-activated carbon. J. Colloid Interface Sci. 2006, 303, 494-502. [CrossRef]

34. Wahlström, N.; Edlund, U.; Pavia, H.; Toth, G.; Jaworski, A.; Pell, A.J.; Choong, F.X.; Shirani, H.; Nilsson, K.P.R.; Richter-Dahlfors, A. Cellulose from the green macroalgae Ulva lactuca: Isolation, characterization, optotracing, and production of cellulose nanofibrils. Cellulose 2020, 27, 3707-3725. [CrossRef]

35. Mayeko, A.K.K.; Vesituluta, P.N.; Di Phanzu, J.N.; Muanda, D.M.W.; Bakambo, G.E.; Lopaka, B.I.; Mulangala, J.M. Adsorption de la quinine bichlorhydrate sur un charbon actif peu coûteux à base de la Bagasse de canne à sucre imprégnée de l'acide phosphorique. Int. J. Biol. Chem. Sci. 2012, 6. [CrossRef]

36. Adamson, W. Physical Chemistry of Surfaces, 4th ed.; John Wiley \& Sons: Hoboken, NJ, USA, 1982; p. 373.

37. El-Jamal, M.M.; Ncibi, M.C. Biosorption of methylene blue by chaetophora elegans algae: Kinetics, equilibrium and thermodynamic studies. Acta Chim. Slov. 2012, 59, 24-31. [PubMed]

38. Lagergren, S. Zur theorie der sogenannten adsorption geloster stoffe. Kungliga Svenska Vetenskapsakademiens. Handlingar 1898, 24, 1-39.

39. Ho, Y.S. Adsorption of Heavy Metals from Waste Streams by Peat; University of Birmingham: Birmingham, UK, 1995.

40. Weber, W.J.; Morris, J.C. Kinetics of adsorption carbon from solutions. J. Sanit. Eng. Div. 1963, 89, 31-60. [CrossRef]

41. Chien, S.H.; Clayton, W.R. Application of Elovich Equation to the Kinetics of Phosphate Release and Sorption in Soils. Soil Sci. Soc. Am. J. 1980, 44, 265-268. [CrossRef]

42. Hamdaoui, O. Batch study of liquid-phase adsorption of methylene blue using cedar sawdust and crushed brick. J. Hazard. Mater. 2006, 135, 264-273. [CrossRef]

43. Weber, T.W.; Chakravorti, R.K. Pore and solid diffusion models for fixed-bed adsorbers. AIChE J. 1974, 20, 228-238. [CrossRef]

44. Liu, Y.; Wang, J.; Zheng, Y.; Wang, A. Adsorption of methylene blue by kapok fiber treated by sodium chlorite optimized with response surface methodology. Chem. Eng. J. 2012, 184, 248-255. [CrossRef]

45. El-Sikaily, A.; El Nemr, A.; Khaled, A.; Abdelwehab, O. Removal of toxic chromium from wastewater using green alga Ulva lactuca and its activated carbon. J. Hazard. Mater. 2007, 148, 216-228. [CrossRef]

46. Tchuifon, D.R.T. Biosorption of amaranth red in aqueous solution onto treated and untreated lignocellulosic materials (pineapple peelings and coconut shells). J. Mater. Environ. Sci. 2017, 8, 4199-4212.

47. Liang, S.; Guo, X.; Feng, N.; Tian, Q. Isotherms, kinetics and thermodynamic studies of adsorption of Cu2+ from aqueous solutions by $\mathrm{Mg} 2+/ \mathrm{K}+$ type orange peel adsorbents. J. Hazard. Mater. 2010, 174, 756-762. [CrossRef]

48. M'Sakni, N.H.; Majdoub, H.; Roudesli, S.; Picton, L.; Le Cerf, D.; Rihouey, C.; Morvan, C. Composition, structure and solution properties of polysaccharides extracted from leaves of Mesembryanthenum crystallinum. Eur. Polym. J. 2006, 42, 786-795. [CrossRef]

49. Al-Qodah, Z.; Al-Shannag, M.; Amro, A.; Assirey, E.; Bob, M.; Bani-Melhem, K.; Alkasrawi, M. Impact of surface modification of green algal biomass by phosphorylation on the removal of copper(II) ions from water. Turk. J. Chem. 2017, 41, 190-208. [CrossRef]

50. Bartošová, A.; Blinová, L.; Gerulová, K. Characterisation Of Polysacharides And Lipids From Selected Green Algae Species By FTIR-ATR Spectroscopy. Res. Pap. Fac. Mater. Sci. Technol. Slovak Univ. Technol. 2015, 23, 97-102. [CrossRef]

51. Liu, L.; Fan, S.; Li, Y. Removal Behavior of Methylene Blue from Aqueous Solution by Tea Waste: Kinetics, Isotherms and Mechanism. Int. J. Environ. Res. Public Heal. 2018, 15, 1321. [CrossRef]

52. Xia, Y.; Yao, Q.; Zhang, W.; Zhang, Y.; Zhao, M. Comparative adsorption of methylene blue by magnetic baker's yeast and EDTAD-modified magnetic baker's yeast: Equilibrium and kinetic study. Arab. J. Chem. 2019, 12, 2448-2456. [CrossRef] 
53. Rahmawati, F.; Ridassepri, A.F.; Chairunnisa; Wijayanta, A.T.; Nakabayashi, K.; Miyawaki, J.; Miyazaki, T. Carbon from Bagasse Activated with Water Vapor and Its Adsorption Performance for Methylene Blue. Appl. Sci. 2021, 11, 678. [CrossRef]

54. Ijagbemi, C.O.; Chun, J.I.; Han, D.H.; Cho, H.Y.; O, S.J.; Kim, D.S. Methylene Blue adsorption from aqueous solution by activated carbon: Effect of acidic and alkaline solution treatments. J. Environ. Sci. Heal Part A 2010, 45, 958-967. [CrossRef] [PubMed]

55. Jawad, A.H.; Ngoh, Y.S.; Radzun, K.A. Utilization of watermelon (Citrullus lanatus) rinds as a natural low-cost biosorbent for adsorption of methylene blue: Kinetic, equilibrium and thermodynamic studies. J. Taibah Univ. Sci. 2018, 12, 371-381. [CrossRef]

56. Jawad, A.H.; AbdulHameed, A.S.; Mastuli, M.S. Acid-factionalized biomass material for methylene blue dye removal: A comprehensive adsorption and mechanism study. J. Taibah Univ. Sci. 2020, 14, 305-313. [CrossRef]

57. Annadurai, G.; Juang, R.-S.; Lee, D.-J. Use of cellulose-based wastes for adsorption of dyes from aqueous solutions. J. Hazard. Mater. 2002, 92, 263-274. [CrossRef]

58. Seghier, A.; Hadjel, H.; Benderdouche, N. Sorption of Methylene Blue Dye from Aqueous Solution Using an Agricultural Waste. Trends Green Chem. 2017, 3. [CrossRef]

59. Deokar, R. Enteromorpha Intestinalis/: Low Cost Biosorbents for Biosorption Methylene Blue. Int. J. Recent Sci. Res. 2016, 7, 9291-9297.

60. Trabelsi, L.; M'Sakni, N.H.; Ouada, H.B.; Bacha, H.; Roudesli, S. Partial characterization of extracellular polysaccharides produced by cyanobacterium Arthrospira platensis. Biotechnol. Bioprocess Eng. 2009, 14, 27-31. [CrossRef]

61. Ovchinnikov, O.; Evtukhova, A.V.; Kondratenko, T.; Smirnov, M.S.; Khokhlov, V.; Erina, O. Manifestation of intermo-lecular interactions in FTIR spectra of methylene blue molecules. Vib. Spectrosc. 2016, 86, 181-189. [CrossRef]

62. Abou, O.; Abdellaoui, H.Y.; Laabd, M.; El Ouardi, M.; Brahmi, Y.; Iazza, M.; Abou Oualid, J. Eco-Efficient Green Seaweed Codium decorticatum Biosorbent for Textile Dyes: Characterization, Mechanism, Recyclability, and RSM Optimization. ACS Omega 2020, 5, 22192-22207. [CrossRef]

63. Deokar, R. Biosorption of Methylene Blue and Malachite Green From Binary Solution onto Ulva lactuca. Int. Jour. Microbiol. Appl. Sci. 2014, 3, 295-304.

64. Karim, A.; Mounir, B.; Hachkar, M.; Bakasse, M.; Yaacoubi, A. Élimination du colorant basique « Bleu de Méthylène » en solution aqueuse par l'argile de Safi. Rev. Sci. Eau 2010, 23, 375.

65. Gupta, V.; Mittal, A.; Gajbe, V. Adsorption and desorption studies of a water soluble dye, Quinoline Yellow, using waste materials. J. Colloid Interface Sci. 2005, 284, 89-98. [CrossRef]

66. Tsai, W.-T.; Hsu, H.-C.; Su, T.-Y.; Lin, K.-Y.; Lin, C.-M.; Dai, T.-H. The adsorption of cationic dye from aqueous solution onto acid-activated andesite. J. Hazard. Mater. 2007, 147, 1056-1062. [CrossRef] [PubMed]

67. Bennani Karim, A.; Mounir, B.; Hachkar, M.; Bakasse, M.; Rais, Z.; Yaacoubi, A. Dynamic adsorption of BR46 dye and raw textile effluent on Moroccan clay to solve the drought problem. J. Water Sci. Environ. Technol. 2017, 2, 2508-9250.

68. Namasivayam, C.; Muniasamy, N.; Gayatri, K.; Rani, M.; Ranganathan, K. Removal of dyes from aqueous solutions by cellulosic waste orange peel. Bioresour. Technol. 1996, 57, 37-43. [CrossRef]

69. Uddin, M.T.; Rahman, M.A.; Rukanuzzaman, M.; Islam, M.A. A potential low cost adsorbent for the removal of cationic dyes from aqueous solutions. Appl. Water Sci. 2017, 7, 2831-2842. [CrossRef]

70. Bilal, M.; Rasheed, T.; Sosa-Hernández, J.E.; Raza, A.; Nabeel, F.; Iqbal, H.M.N. Biosorption: An Interplay between Marine Algae and Potentially Toxic Elements-A Review. Mar. Drugs 2018, 16, 65. [CrossRef] [PubMed]

71. Doğan, M.; Alkan, M. Removal of methyl violet from aqueous solution by perlite. J. Colloid Interface Sci. 2003, $267,32-41$. [CrossRef]

72. Alzaydien, A.S. Adsorption of Methylene Blue from Aqueous Solution onto a Low-Cost Natural Jordanian Tripoli. Am. J. Environ. Sci. 2009, 5, 197-208. [CrossRef]

73. Low, K.S.; Chow, S.W. Chrome Sludge as an Adsorbent for Colour Removal AU-Lee, C. K. Environ. Technol. 1996, 17, 1023-1028.

74. Acemioglu, B. Batch kinetic study of sorption of methylene blue by perlite. Chem. Eng. J. 2005, 106, 73-81. [CrossRef]

75. Panday, K.K.; Prasad, G.; Singh, V.N. Use of wollastonite for the treatment of Cu(II) rich effluents. Water Air Soil Pollut. 1986, 27, 287-296. [CrossRef]

76. Juang, R.-S.; Chen, M.-L. Application of the Elovich Equation to the Kinetics of Metal Sorption with Solvent-Impregnated Resins Ind. Eng. Chem. Res. 1997, 36, 813-820. [CrossRef]

77. Chowdhury, S.; Saha, P.D. Biosorption of methylene blue from aqueous solutions by a waste biomaterial: Hen feathers. Appl. Water Sci. 2012, 2, 209-219. [CrossRef]

78. Maurya, R.; Ghosh, T.; Paliwal, C.; Shrivastav, A.; Chokshi, K.; Pancha, I.; Ghosh, A.; Mishra, S. Biosorption of Methylene Blue by De-Oiled Algal Biomass: Equilibrium, Kinetics and Artificial Neural Network Modelling. PLoS ONE 2014, 9, e109545. [CrossRef] [PubMed]

79. Hameed, B.; El-Khaiary, M. Removal of basic dye from aqueous medium using a novel agricultural waste material: Pumpkin seed hull. J. Hazard. Mater. 2008, 155, 601-609. [CrossRef]

80. Chaleshtori, A.A.; Meghadddam, F.M.; Sadeghi, M.M.; Rahimi, R.R.; Hemati, S.; Ahmadi, A.A. Removal of acid red 18 (Azo-dye) from aqueous solution by adsorption onto activated charcoal prepared from almond shell. J. Environ. Sci. Manag. 2017, 20, 9-16.

81. Kamga, F.T. Modeling adsorption mechanism of paraquat onto Ayous (Triplochiton scleroxylon) wood sawdust. Appl. Water Sci. 2018, 9, 1. [CrossRef] 
82. Pathania, D.; Sharma, S.; Singh, P. Removal of methylene blue by adsorption onto activated carbon developed from Ficus carica bast. Arab. J. Chem. 2017, 10, S1445-S1451. [CrossRef]

83. Rafatullah, M.; Sulaiman, O.; Hashim, R.; Ahmad, A. Adsorption of methylene blue on low-cost adsorbents: A review. J. Hazard. Mater. 2010, 177, 70-80. [CrossRef]

84. Yu, J.-X.; Li, B.-H.; Sun, X.-M.; Yuan, J.; Chi, R.-A. Polymer modified biomass of baker's yeast for enhancement adsorption of methylene blue, rhodamine B and basic magenta. J. Hazard. Mater. 2009, 168, 1147-1154. [CrossRef]

85. Yu, J.-X.; Li, B.-H.; Sun, X.-M.; Yuan, J.; Chi, R.-A. Poly(Amic Acid)-Modified Biomass of Baker's Yeast for Enhancement Adsorption of Methylene Blue and Basic Magenta. Appl. Biochem. Biotechnol. 2009, 160, 1394-1406. [CrossRef]

86. Marungrueng, K.; Pavasant, P. High performance biosorbent (Caulerpa lentillifera) for basic dye removal. Bioresour. Technol. 2007, 98, 1567-1572. [CrossRef]

87. Ncibi, M.C.; Ben Hamissa, A.; Fathallah, A.; Kortas, M.; Baklouti, T.; Mahjoub, B.; Seffen, M. Biosorptive uptake of methylene blue using Mediterranean green alga Enteromorpha spp. J. Hazard. Mater. 2009, 170, 1050-1055. [CrossRef]

88. Gulnaz, O.; Kaya, A.; Matyar, F.; Arikan, B. Sorption of basic dyes from aqueous solution by activated sludge. J. Hazard. Mater. 2004, 108, 183-188. [CrossRef] [PubMed]

89. Maurya, N.S.; Mittal, A.K.; Cornel, P.; Rother, E. Biosorption of dyes using dead macro fungi: Effect of dye structure, ionic strength and pH. Bioresour. Technol. 2006, 97, 512-521. [CrossRef] [PubMed]

90. Low, K.; Lee, C.; Heng, L. Sorption of basic dyes byHydrilla verticillata. Environ. Technol. 1994, 15, 115-124. [CrossRef]

91. Vilar, V.J.P.; Botelho, C.M.S.; Boaventura, R.A.R. Methylene blue adsorption by algal biomass based materials: Biosorbents characterization and process behaviour. J. Hazard. Mater. 2007, 147, 120-132. [CrossRef]

92. Waranusantigul, P.; Pokethitiyook, P.; Kruatrachue, M.; Upatham, E. Kinetics of basic dye (methylene blue) biosorption by giant duckweed (Spirodela polyrrhiza). Environ. Pollut. 2003, 125, 385-392. [CrossRef]

93. Caparkaya, D.; Cavas, L. Biosorption of Methylene Blue by a Brown Alga Cystoseira barbatula Kutzing. Acta Chim. Slov. 2008, 55, 547-553.

94. Nacèra, Y.; Aicha, B. Equilibrium and kinetic modelling of methylene blue biosorption by pretreated dead streptomyces rimosus: Effect of temperature. Chem. Eng. J. 2006, 119, 121-125. [CrossRef]

95. Fu, Y.; Viraraghavan, T. Removal of a Dye from an Aqueous Solution by the Fungus Aspergillus niger. Water Qual. Res. J. 2000, 35, 95-112. [CrossRef]

96. Cengiz, S.; Cavas, L. Removal of methylene blue by invasive marine seaweed: Caulerpa racemosa var. cylindracea. Bioresour. Technol. 2008, 99, 2357-2363. [CrossRef] [PubMed]

97. Vakili, M.; Rafatullah, M.; Yuan, J.; Zwain, H.M.; Mojiri, A.; Gholami, Z.; Gholami, F.; Wang, W.; Giwa, A.S.; Yu, Y.; et al. Nickel ion removal from aqueous solutions through the adsorption process: A review. Rev. Chem. Eng. 2019. [CrossRef] 